\title{
Basement Membranes: Cell Scaffoldings and Signaling Platforms
}

\author{
Peter D. Yurchenco \\ Robert Wood Johnson Medical School, Piscataway, New Jersey 08854 \\ Correspondence: yurchenc@umdnj.edu
}

Basement membranes are widely distributed extracellular matrices that coat the basal aspect of epithelial and endothelial cells and surround muscle, fat, and Schwann cells. These extracellular matrices, first expressed in early embryogenesis, are self-assembled on competent cell surfaces through binding interactions among laminins, type IV collagens, nidogens, and proteoglycans. They form stabilizing extensions of the plasma membrane that provide cell adhesion and that act as solid-phase agonists. Basement membranes play a role in tissue and organ morphogenesis and help maintain function in the adult. Mutations adversely affecting expression of the different structural components are associated with developmental arrest at different stages as well as postnatal diseases of muscle, nerve, brain, eye, skin, vasculature, and kidney.

$T_{\text {titid }}^{\text {he }}$ he basement membrane (basal lamina) was first described in muscle as a "membranaceous sheath of the most exquisite delicacy" (Bowman 1840). Microscopists subsequently identified basement membranes in nearly all tissues. In the late 1970s, the discovery of the basement membrane-rich EHS tumor led to the isolation of abundant quantities of laminin, type IV collagen, nidogen (entactin), and perlecan, enabling elucidation of their biochemical and cell-interactive properties and opening a door to an understanding of structure and function of basement membranes at a molecular level.

Basement membranes are layered cell-adherent extracellular matrices (ECMs) that form part of tissue architecture, contributing both to embryonic differentiation and the maintenance of adult functions. They are evolutionarily ancient structures, likely appearing when organized communities of animal cells first emerged. These matrices serve as an extension of the plasma membrane, protecting tissues from disruptive physical stresses, and provide an interactive interface between cell and surrounding environment that can mediate local and distant signals within and between these compartments. Such signals appear to be largely processed through integrins, growth factor interactions, and dystroglycan. Basement membrane-dependent functions include the promotion of strong epidermal/dermal attachment, stabilization of the skeletal muscle sarcolemma, selectivity of glomerular filtration, and establishment of epithelial and glial cell polarization. Assembly of a functionally active basement membrane depends on the binding interactions among the large carbohydrate-modified

Editors: Richard Hynes and Kenneth Yamada

Additional Perspectives on Extracellular Matrix Biology available at www.cshperspectives.org

Copyright (C) 2011 Cold Spring Harbor Laboratory Press; all rights reserved; doi: 10.1101/cshperspect.a004911

Cite this article as Cold Spring Harb Perspect Biol 2011;3:a004911 
P.D. Yurchenco

proteins, each consisting of an array of distinct domains with unique binding properties. These components, in turn, are organized into higher ordered supramolecular assemblies that engage cell surface receptors in a developmentally and tissue-specific manner. In this review models of structure will be related to those of function based on a consideration of morphological, biochemical, cell biological, developmental, and genetic information.

\section{SUPRAMOLECULAR ARCHITECTURE}

Each basement membrane contains at least one member of the heterotrimeric laminin family, one or two nidogens, the heparan sulfate proteoglycans (HSPGs) perlecan and/or agrin, and one or more of the variants of type IV collagens (Fig. 1). We recognize these components as major contributors to the formation of the basic architectural scaffolding and array of interactive ligands. The laminin and collagen isoforms possess differences in their assembly, receptorbinding, and/or subsequent cross-linking, allowing variations in final structure, signaling, and stability. Laminins, type IV collagens, perlecan, and agrin are large macromolecules ranging from $\sim 75 \mathrm{~nm}$ to $\sim 400 \mathrm{~nm}$ in greatest length. In typical thin basement membranes (50-100 nm thick), the basic components are likely organized into a single molecular layer with the long axes of laminin and collagen parallel to the surface. In thicker basement membranes, such as those of Reichert's membrane, the renal glomerulus, lens capsule, and EHS tumor matrix, the interior basement membrane molecules reside beyond the reach of receptors and interact only through intercomponent architectural bonds. Collagens type XVIII, XV, and VI are found at the basement membrane/stromal interface and are thought to mediate their attachment. Additionally, fibronectin, usherin, bamacan, nephronectin, papilin, netrins, and other components can be found within basement membranes, adding additional receptor-binding activities (e.g., nephronectin) and/or modulating structure (e.g., netrin-4). All of the components show differential developmental and tissue-specific expression patterns. ${ }^{1}$

By electron microscopy of glutaraldehydefixed and heavy-metal-impregnated thin sections, the basement membrane is typically seen as consisting of an electron-dense layer (lamina densa) separated from the plasma membrane by an electron-lucent layer (lamina lucida). However, the significance of this distinct morphology was brought into question by the technique of rapid freeze-substitution in which a homogenous ultrastructure was observed (Chan et al. 1993; Chan and Inoue 1994; Miosge 2001). A detailed study of Reichert's membrane revealed a three-dimensional branching network of fine filaments and cords (Inoue et al. 1983). By ultrathin high-angle platinum/carbon shadowing, the supramolecular organization was seen to consist of a branching network of type IV collagen containing endto-end and lateral associations and a mesh of short interconnecting struts corresponding to the laminin polymer in which the combined laminin/collagen network "pore" size was on the order of $10 \mathrm{~nm}$ (Yurchenco and Ruben 1987; Yurchenco et al. 1992).

\section{BASEMENT MEMBRANE SELF-ASSEMBLY AND RECEPTOR INTERACTIONS}

Basement membranes have been deduced to assemble (Fig. 2) through a multistep process that is substantially mass action-driven (selfassembly) and that is initiated by the binding of laminins to competent (i.e., laminin-binding) cell surfaces (Smyth et al. 1998; Li et al. 2002; Li et al. 2005b; McKee et al. 2007; McKee et al. 2009). The intercomponent binding interactions and polymerizations of laminins and type IV collagen that create a relevant scaffold matrix were first identified and characterized by a study of purified components in vitro. Assembly on cells, however, has been found to be

\footnotetext{
${ }^{1}$ The reader should be aware of a comprehensive mouse E16.5 expression reference map of the different basement membrane components, generated by K. Sekiguchi and colleagues, to be found at the website http://www.matrixome. $\mathrm{com} / \mathrm{bm}$.
} 
facilitated by anchorage to select cell surfaces that serves to increase the local surface concentration of components, promoting the interactions (Kalb and Engel 1991; Li et al. 2005b; McKee et al. 2007). This initial anchoring interaction appears to occur primarily through the laminin LG domains (Figs. 1-3) that can bind to sulfated glycolipids, integrins, dystroglycan, and heparan sulfates. Cell surface anchorage then enables the accumulation of nidogen, type IV collagen, perlecan, and agrin to the nascent laminin scaffold. Although nonlaminin components have the potential to bind directly to cell surface integrins and/or dystroglycan, they appear to be unable to accumulate on the cell surface to any appreciable degree in the absence of laminins. Cell control of assembly, biological activity, and subsequent state can occur through the regulation of component expression, receptor expression, receptor activation, site-specific cleavage of laminin domains to alter their interactions, enzymatic cross-linking, and turnover/degradation by matrix metalloproteinases (MMPs) and other proteolytic enzymes. In addition, there is evidence to suggest that the organization of the basement membrane, such as its density and surface patterning, can be modulated by the cytoskeleton in a dynamic fashion through its receptor connections (Colognato et al. 1999).

\section{Laminin Family}

Each laminin $(\sim 400-800 \mathrm{kDa})$ is a heterotrimer consisting of one each of five $\alpha$, four $\beta$, and three $\gamma$ subunits joined through a long coiled-coil domain (Parsons et al. 2002; Aumailley et al. 2005) (Figs. 1 and 2). Charged residues within the heptad repeats of the coiled-coil restrict the number of allowed heterotrimers (Beck et al. 1993; Macdonald et al. 2010) to generate the following (confirmed) vertebrate heterotrimers: laminins-111 (i.e. $\alpha 1 \beta 1 \gamma 1$ ), $121,211,213,221,311,312,321,332,411$, 421, 422, 423, 511, 521, and 523 (Aumailley et al. 2005; Macdonald et al. 2010). The $\alpha 3 \mathrm{~A}$ subunit, which lacks the amino-terminal domains of the short arm, also exists as a longer $(\alpha 3 B)$ splice-variant with a full short arm. In general, the laminins differ from each other on the basis of short arm domain composition, $\alpha$-subunit LG integrin- and dystroglycanbinding affinities/specificities, and posttranslational proteolytic processing of amino- and carboxy-terminal globular domains. The $\alpha$ subunits are largely responsible for cell surface adhesion and receptor interactions but also contribute to self-assembly. The $\beta$ - and $\gamma$ - subunits primarily play a structural role, mediating polymerization and nidogen-binding but also serve to modulate receptor-binding. Laminins111 and $511(\alpha 5 \beta 1 \gamma 1)$, the first to be expressed in mammalian embryos, are essential for basement membrane assembly and early embryonic morphogenesis (Smyth et al. 1999; Huang et al. 2003; Miner et al. 2004; Urbano et al. 2009). The laminin $\alpha 1$ subunit was found to be required for assembly of the extraembryonic Reichert's membrane whereas formation of the basement membrane of the embryonic plate required either the $\operatorname{Lm} \alpha 1$ or $\operatorname{Lm} \alpha 5$ subunit (Miner et al. 2004). Inactivation of the laminin- $\alpha 5$ gene (Lama5) coding for the most widely expressed laminin subunit resulted in multiple embryonic defects including syndactyly, failure of neural tube closure, renal agenesis/failure of glomerulogenesis, and placental vessel malformations (Miner et al. 1998). Inactivation of the genes coding for the laminin $\beta 2, \alpha 2$, and $\alpha 4$ subunits, which are expressed later in a more tissue-restricted manner caused defects of the neuromuscular junction/glomerulus, skeletal muscle/peripheral nerve, and microvasculature/peripheral nerve, respectively, with survival into the post-natal period (Noakes et al. 1995a; Noakes et al. 1995b; Miyagoe et al. 1997; Thyboll et al. 2002; Wallquist et al. 2005).

Basement membranes are detected on some but not all cell surfaces. For example, basement membranes are found on developing Schwann cells but not on adjacent naked axons, and similarly they are found on the basal aspect of epithelia but not on adjacent fibroblasts. Because it appears that laminins are unable to accumulate on cells in the absence of the cell-adhesive LG domains, because basement membranes do not assemble on cell surfaces in the absence of laminins, and because the components can 
P.D. Yurchenco

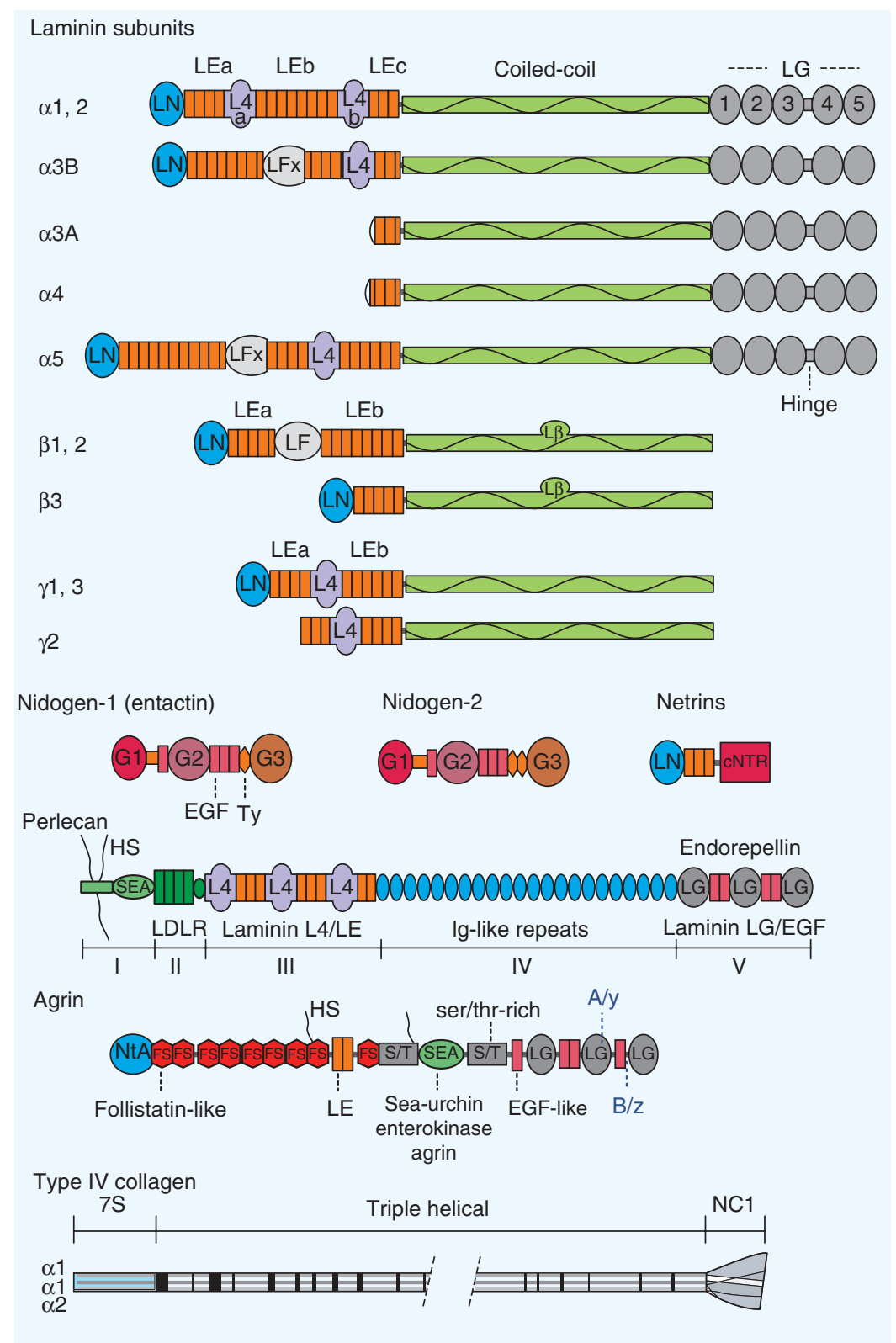

Figure 1. Basement membrane proteins and domains. The large glycosylated proteins of the basement membrane consist of tandem repeats of various protein motifs and likely evolved through gene duplication. The laminin subunits consist of arrays that can contain amino-terminal globules (LN domain), laminin-type epidermal growth factor-like repeats that form rodlike regions (each an LE domain that contains four cystine pairs), L4 domains (globule interrupting two half-LE domains such that the second and fourth cysteines bridge across the base of the globule), LF (unique globule of $\beta$-subunits), a modified LF domain (here designated LFx), a long coiled-coil domain (a knoblike L $\beta$ subdomain interrupts the heptad-repeats of the $\beta$ subunits), and terminal LG domains (carboxy-terminal laminin globular domains, each a $\beta$-sandwich found in $\alpha$-subunits). Each laminin consists of an $\alpha, \beta$, and $\gamma$ subunit joined in parallel at the coiled-coil domain and stabilized by disulfide pairs between each subunit at the LE/coiled-coil junction and between the $\beta$ and $\gamma$ subunits near the carboxyl terminus. The domain nomenclature shown is as recently revised (Aumailley et al. 2005). (Legend continued on following page.) 
diffuse in the extracellular space, it is likely that the selective competency to assemble a basement membrane is regulated by cell surface expression of laminin LG-binding molecules. In cultured Schwann cells this selectivity has been found to be dependent on the presence of galactosyl-sulfatide, a laminin-binding sulfated glycolipid found on outer leaflet of Schwann cell plasma membranes ( $\mathrm{Li}$ et al. 2005b). Embryonic fibroblasts, which normally do not assemble basement membranes, will do so if sulfatides are intercalated into their plasma membranes and if incubated in the presence of laminin.

\section{Integrin Interactions}

Integrins are transmembrane heterodimeric receptors that mediate signaling initiated by ligand binding. They act in a bidirectional fashion and are modulated by the mechanical properties of the cell-ECM interface (reviewed in Berrier and Yamada 2007; Takagi 2007). Following ligand binding to ECM macromolecules, integrins undergo clustering that concentrates intracellular components involved in signaling. Integrins affect actin organization through modulation of small GTPase activities and can provide firm anchorage to the cell through linkages formed with recruited cytoplasmic proteins to F-actin. Integrin signaling affects gene regulation, and can alter cell polarity and shape, cell migration, proliferation, differentiation, and survival. Basement membrane components, especially the laminins, interact with a number of related $\beta 1$-integrins $(\alpha 1 \beta 1, \alpha 2 \beta 1, \alpha 3 \beta 1, \alpha 6 \beta 1$, and $\alpha 7 \beta 1$ ). Exclusive signaling pathways have not been clearly identified for these integrins compared with other $\beta 1$ integrins; however, the combination of receptors engaged with their specific and different ligand affinities and/or the mechanical attributes of the basement membrane scaffold may determine the uniqueness of information-transfer to the cell. The interaction between Laminin-332 and the $\alpha 6 \beta 4$ integrin in hemidesmosome (HD) assembly merits special note and is discussed ahead.

The LG1-3 domain cluster, located at the end of the long arm of different laminins, provide what is thought as the principal integrininteraction sites, binding to $\alpha 6 \beta 1, \alpha 6 \beta 4, \alpha 7 \beta 1$, and $\alpha 3 \beta 1$ (Nishiuchi et al. 2006). Genetic analysis with laminin-class integrin subunit-deficient mice has revealed the importance of the LG domain integrin subunits for tissue and organ morphogenesis, including epidermal/ dermal attachment, brain development, and glomerular and lung development (GeorgesLabouesse et al. 1996; Kreidberg et al. 1996; Di Persio et al. 1997; Mayer et al. 1997; GeorgesLabouesse et al. 1998). Binding of these integrins depends on contributions arising from $\gamma 1$ and $\beta 1$ subunit coiled-coil domain sequences located in the vicinity of the LG domains (Ido et al. 2007; Taniguchi et al. 2009). A $\gamma 1$-subunit glutamic acid residue (E1607) important for integrin-binding is absent in the $\gamma 3$ laminin subunit (Ido et al. 2008). Although little is known about this subunit that is otherwise quite homologous to $\gamma 1$, this new finding may

Figure 1. (Continued) Nidogens are laminin-binding proteins that possess their own globular domains (G1-G3) separated by EGF-like domains (generally six cysteines each), thyroglobulin type I repeats (Ty), and a G1-adjacent unique rodlike segment. Netrins possess a laminin-type LN domain, LE repeats, and a unique carboxy-terminal netrin domain. Perlecan consists of five regions consisting of an amino-terminal domain from which project heparan sulfates (HS), SEA domains (sea urchin enterokinase and agrin domain), LDLreceptor repeats, laminin short-arm region consisting of duplicated L4 and LE domains, immunoglobulin (Ig) repeats, and laminin-type LG domains separated by EGF-type repeats. Agrins consist of an amino-terminal laminin binding-domain (NtA), follistatin-like repeats (FS), LE domains, serine/threonine-rich (S/T) domains, and LG domains flanked by EGF-like repeats. Splice variations at two sites impart heparin-binding (A/y insert) and acetylcholine-clustering activity $(\mathrm{B} / \mathrm{z}$ insert) found in neural agrin. A domain map of the most common type IV collagen heterotrimer $\left(\alpha 1_{2} \alpha 2\right.$ [IV]) is shown. The triple helical domain, containing multiple interruptions of the gly-x-y repeat (vertical bars), imparts flexibility and is thought to facilitate branching during assembly. 
P.D. Yurchenco
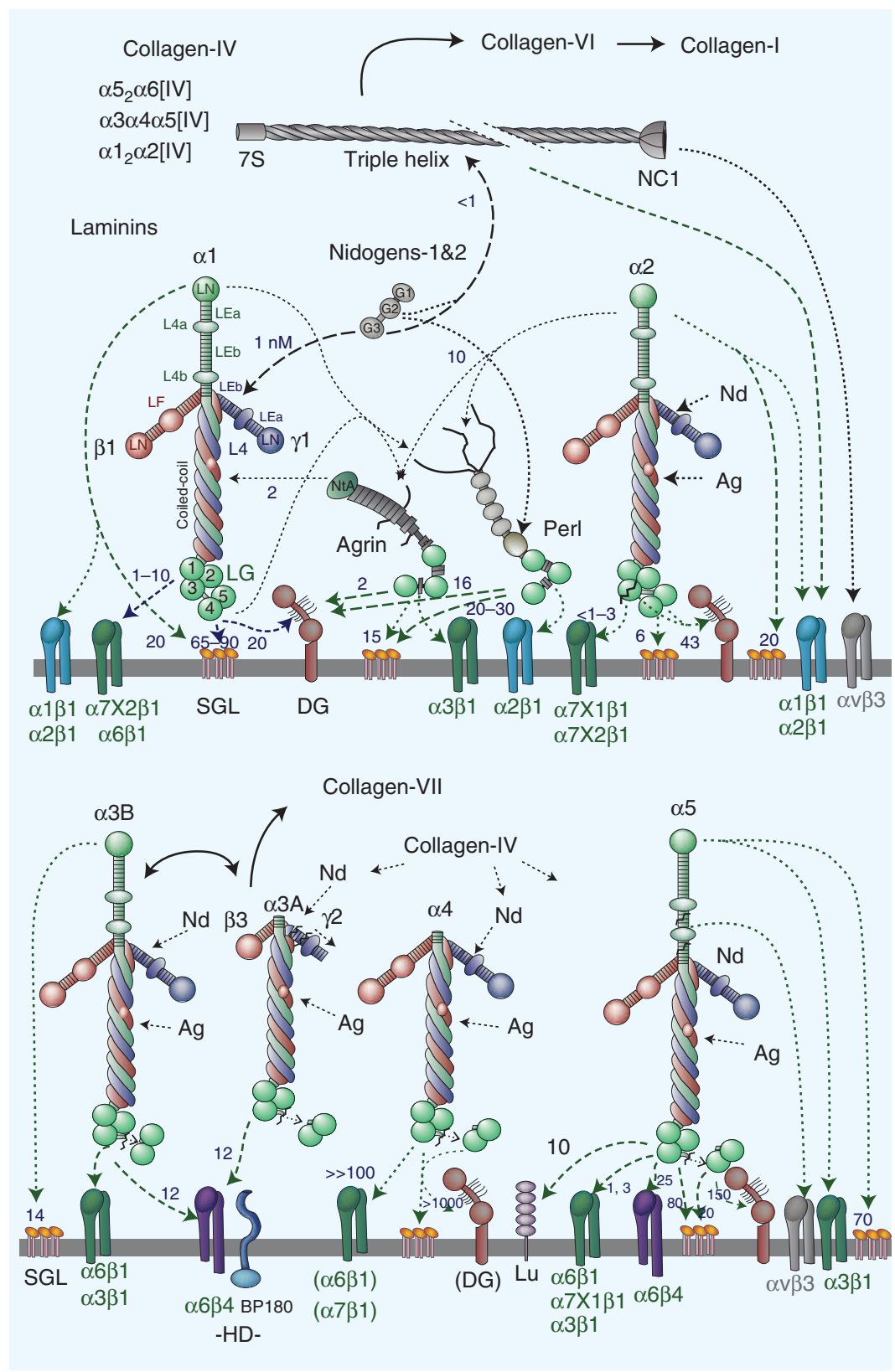

Figure 2. Basement membrane components, receptors, and intermolecular binding. Basement membranes contain laminins, nidogens (Nd), type IV collagens, perlecan ( perl), and agrins (Ag). Receptors and other cell surface binding molecules include integrins, dystroglycan (DG), the Lutheran glycoprotein (Lu), and sulfated glycolipids such as sulfatides (SGL). Laminin-3A32 is involved in hemidesmosome (HD) assembly, interacting with the $\alpha 6 \beta 4$ integrin and BP180. Laminins differ based on their complement of domains, ability to polymerize, proteolytic processing, receptor-binding repertoire, and receptor affinities. Relative strong (heavy solid and dashed lines) and weak (thin dashed lines) interactions are indicated with heavy and thin lines with approximate dissociation constants are indicated where known (small numbers in nM values) (Denzer et al. 1998; Gesemann et al. 1998; Hopf et al. 1999; Talts et al. 1999; Talts et al. 2000; Hopf et al. 2001; Nielsen and Yamada 2001; Ries et al. 2001; Garbe et al. 2002; Smirnov et al. 2002; Nishiuchi et al. 2006; Harrison et al. 2007). 
represent one of the functional modifications that makes this class of laminins unique.

The amino-terminal LN domain of laminin $\alpha$-subunits provides a second cell-adhesive locus that binds to sulfatides, heparin, and (depending on the laminin $\alpha$-subunit) $\alpha 1 \beta 1$, $\alpha 2 \beta 1$ and $\alpha 3 \beta 1$ integrins (Colognato-Pyke et al. 1995; Colognato et al. 1997; Nielsen and Yamada 2001; Garbe et al. 2002). Although the developmental and physiological significance of the LNintegrin interactions remain to be established, the combination of different cell surface binding activities within close proximity within the LN domain may reflect a need for a coordination of integrin activity with the cell adhesiveness provided through sulfated glycolipids and cell surface heparan sulfates. A prediction is that the laminin would be forced to orient itself parallel to the cell surface through its LG and LN interactions during basement membrane assembly (Fig. 2).

\section{Dystroglycan Interactions}

Dystroglycan is part of a complex (dystrophinglycoprotein complex, or DGC) that forms a link in a chain of bound proteins extending from laminins, agrins, and perlecan to $\alpha$-dystroglycan to $\beta$-dystroglycan to dystrophin/utrophin to F-actin (reviewed in Barresi and Campbell 2006). In skeletal muscle the complex consists of $\alpha$ - and $\beta$-dystroglycan (two proteins arising from one gene product through proteolysis, the latter transmembrane), sarcoglycans (four transmembrane subunits), $\alpha$-dystrobrevin, dystrophin (a spectrin-like protein), nitric oxide synthase, and syntrophins. In other tissues, $\beta$ dystroglycan is found bound to homologs of dystrophin that include utrophin (also found in muscle), Dp160 and Dp116. Dystrophin and utrophin bind in a noncompetitive manner to F-actin with similar affinities (Rybakova et al. 2006). Dystroglycan plays a crucial role in preserving the sarcolemma in the face of muscle contraction/relaxation and is important for development of the Schwann cell nodes of Ranvier, brain cortex laminations, and formation and/or survival of the parietal endoderm (Ervasti and Campbell 1993; Williamson et al.
1997; Cohn et al. 2002; Moore et al. 2002; Nodari et al. 2008). Binding occurs among the mucinous O-linked carbohydrate chains located in the mid-neck region of $\alpha$-dystroglycan with the laminin, perlecan, and agrin LG domains. The LG domains bind to sulfatides and heparin in addition to dystroglycan through clusters of lysine and arginine residues present in overlapping surface patches of the $\beta$-sandwich globular domains (Wizemann et al. 2003; Harrison et al. 2007). In some tissues such as Reichert's membrane, breast epithelium, and skeletal muscle, $\alpha$-dystroglycan may provide the primary anchorage needed for laminin accumulation and basement membrane assembly (Williamson et al. 1997; Henry and Campbell 1998; Weir et al. 2006). In others (e.g., embryonic plate, peripheral nerve, and kidney) this role seems unlikely (Sunada et al. 1995b; Li et al. 2002; Saito et al. 2003; Li et al. 2005b).

Although the structural role as a basement membrane-to-cytoskeletal anchor is well established, there is also evidence to suggest that dystroglycan acts as a signaling receptor (Bozzi et al. 2009). In one study, laminin-111 binding to Schwann cells was reported to activate Src family members in a dystroglycan- and sulfatide-dependent manner, affecting cell survival (Li et al. 2005b). In other studies, Src kinase-dependent syntrophin tyrosine phosphorylation leading to Rac1 activation, heterotrimeric G protein binding syntrophin, and calcium mobilization was detected following the binding of laminins (and laminin terminal LG fragments) to muscle sarcolemmal-rich microsomes (Zhou et al. 2005; Zhou et al. 2006; Zhou et al. 2007; Xiong et al. 2009). Similar effects seen with muscle contraction/stretching led to the proposal that dystroglycan acts as a mechanoreceptor. $\beta$-Dystroglycan, in response to proteolytic cleavage from the extracellular $\alpha$-subunit, has been reported to traffic in an autonomous fashion to the nucleus (Oppizzi et al. 2008). The cytoplasmic tail of $\beta$-dystroglycan was found to be phosphorylated (Y892) by Src tyrosine kinase, apparently in an adhesion-dependent manner, resulting in dystroglycan redistribution to an internal membrane compartment (Sotgia et al. 2003). However, this process may 
P.D. Yurchenco

A
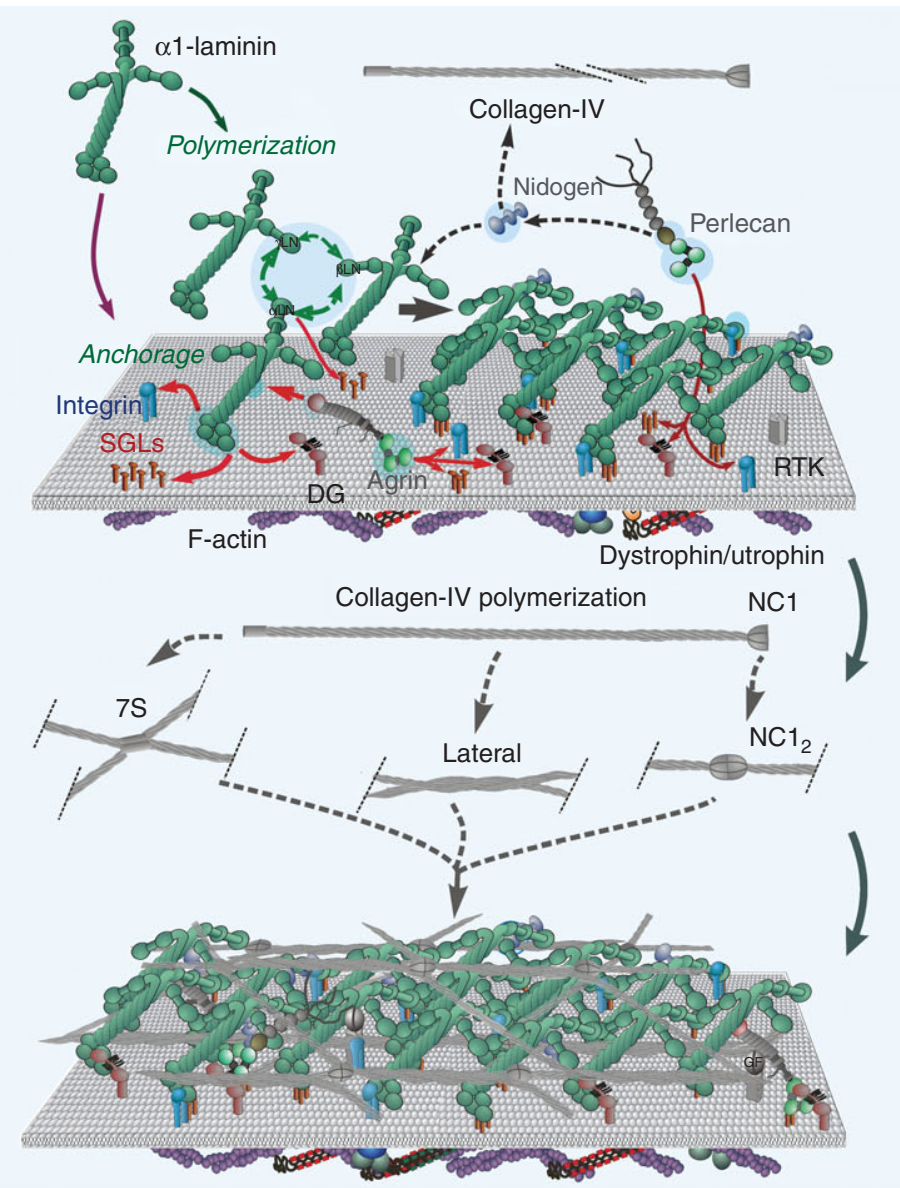

B

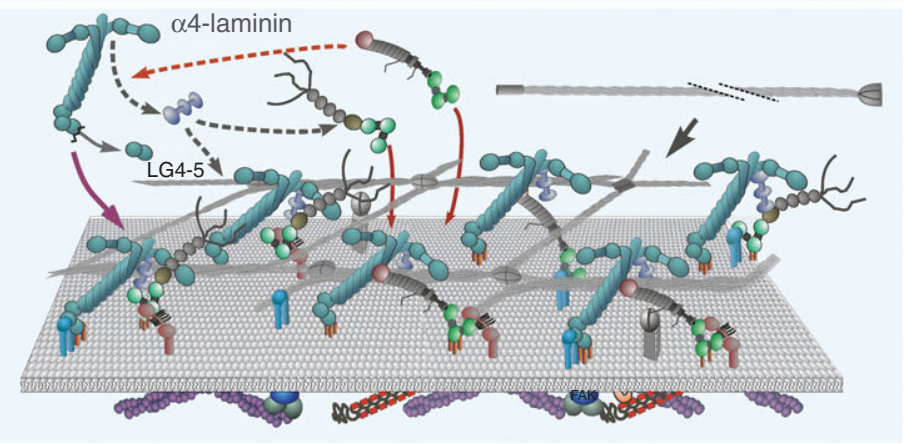

Figure 3. Basement membrane assembly. (A) Steps in the assembly of a basement membrane initiated by a polymerizing laminin. The laminin LG domains bind to a competent cell surface through sulfated glycolipids (SGL), available integrins and $\alpha$-dystroglycan, promoting laminin polymerization through its LN domains. The $\alpha$-LN domain also binds to sulfatides and integrins, forcing the laminin onto its side and enabling activation of a new subset of integrins. Nidogens bind to the coiled-coil domain of laminin and to type IV collagen, forming a stabilizing bridge (the collagen also binds to the developing basement membrane through other poorly characterized interactions). Type IV collagen polymerizes to form a second covalently stabilized network. Agrin and perlecan bind to the laminin coiled-coil and to nidogen respectively and also bind to dystroglycan (DG), integrins, and sulfated glycolipids, establishing collateral linkages to additional receptors. (Legend continued on following page.) 
be one of the regulation of dystroglycan turnover rather than laminin/matrix-induced signaling. In mammary gland epithelial cells, dystroglycan, even in the absence of the cytoplasmic tail, was found to mediate laminin accumulation and polarity-induction, suggesting that the function is one more of increased attachment to the cell surface with the role in epithelial polarization mediated through an indirect mechanism (Weir et al. 2006).

\section{Laminin Polymerization and} LN-Domain Binding

The $\alpha 1-, \alpha 2-, \alpha 3 \mathrm{~B}-$, and $\alpha 5$-laminins, each bearing $\alpha, \beta$, and $\gamma$ subunit LN domains, can self-assemble into polymers (Yurchenco et al. 1985; Yurchenco et al. 1992; Cheng et al. 1997; Garbe et al. 2002). The LN domains appear to require their adjacent LE repeats to fold properly because of an unusual interdomain pattern of disulfide-binding (Kalkhof et al. 2008). Studies with laminin-111 have revealed that selfassembly is calcium-dependent and mediated by cooperative binding among $\alpha, \beta$, and $\gamma$ subunit LN domains to form ternary complexes among adjacent laminins (Yurchenco and Cheng 1993; McKee et al. 2007) (see Fig. 3A). Examination of binding among recombinant LN/LEa fragment pairs confirmed the predicted pairing of $\alpha 1 \mathrm{LN}-\beta 1 \mathrm{LN}, \alpha 1 \mathrm{LN}-\gamma 1 \mathrm{LN}$, and $\beta 1 L N-\gamma 1 L N$ and absence of $\beta 1 L N$ and $\gamma 1 \mathrm{LN}$ self-binding (Odenthal et al. 2004). The analysis also revealed self- $\alpha \mathrm{LN}$ binding, inter$\alpha \mathrm{LN}$ binding, inter- $\beta 2 \mathrm{LN}$ binding, an absence of $\gamma 3 \mathrm{LN}$ interactions with LN/LE domains other than those of $\beta 2$ and $\beta 3$, an absence of $\alpha 2 \mathrm{LN}-\gamma 1 \mathrm{LN}$ binding, and a range of LN-LN affinities, all implying greater complexity of selfassembly, particularly among the laminin isoforms. However, one also needs to consider modifying interactions arising from sites distal to the LEa domain as well as spatial constraints that may affect the rules of self-assembly for intact heterotrimers. Recent studies with recombinant laminin-111 heterotrimers bearing domain modifications favored a strict $\alpha$ $\beta-\gamma$ LN ternary interaction as a requirement for self-assembly and basement membrane formation (McKee et al. 2007; McKee et al. 2009). These studies also revealed that deletion of the $\alpha \mathrm{LN}$ domain (preventing polymerization) resulted in assembly of a laminin-poor, collagenrich ECM and suggested that laminins lacking an $\alpha$-short arm such as laminin-411 would assemble in this alternative manner (Fig. 3B).

Polymerization defects are implicated in a number of developmental abnormalities. The $d y 2 J$ dystrophic mouse, possessing an in-frame deletion within the laminin $\alpha 2 \mathrm{LN}$ domain, is characterized by attenuated muscle sarcolemmal and Schwann cell endoneurial basement membranes, muscle degeneration/regeneration and peripheral nerve amyelination (Sunada et al. 1995a; Colognato and Yurchenco 1999). Missense-mutations of the $\alpha 2$ and $\alpha 1 \mathrm{LN}$ domains have been found to cause a mild neuromuscular and retinal defects respectively, the latter associated with a partial reduction in the ability of the LN domain to bind to its $\beta \mathrm{LN}$ and $\gamma \mathrm{LN}$ partners (Patton et al. 2008; Edwards et al. 2010). Missense mutations clustered within the laminin $\beta 2 \mathrm{LN}$ domain are a cause of Pierson disease, a syndrome characterized by congenital nephrotic syndrome, ocular abnormalities, and neurologic deficits (Matejas et al. 2010).

\section{Laminin-Nidogen Complex and Linkage to Type IV Collagen}

Nidogens- 1 and -2 (entactins) are glycoproteins that possess three globular domains with two intervening rodlike domains and that bind to a number of ECM components (Mayer and

Figure 3. (Continued) Heparin-binding growth factors (GF) bind to the heparan sulfate chains and to their receptor tyrosine kinases (RTK), activating signaling pathways in concert with integrin activation. (B) Steps in the assembly of a basement membrane initiated by a nonpolymerizing laminin. In the case of $\alpha 4$-laminin with weak LG interactions and no $\alpha$-LN domain, anchorage may depend heavily on collateral linkage through agrin and perlecan. The laminin establishes links to type IV collagen through nidogen; however, in the absence of polymerization, the resulting scaffold has a lower laminin density. 
Timpl 1994). One important interaction is the binding of nidogen to the short arm of the laminin $\gamma$ subunit, mediated by sequences within a laminin LE domain and the nidogen carboxy-terminal globule (Fox et al. 1991; Poschl et al. 1994; Poschl et al. 1996; Gohring et al. 1998; Ries et al. 2001; Sasaki et al. 2001; Takagi et al. 2003; Gersdorff et al. 2005). The second and third globular domains of nidogen have been found to bind to type IV collagen at one or more sites to form a bridge composed of high affinity noncovalent interactions among the two polymer-forming proteins of the basement membrane. Knockout of either the nidogenbinding site in the laminin $\gamma 1$ subunit or both nidogens in mice was found to be lethal by birth (and often at earlier stages) associated with defects of lung, heart, kidney, and limb (Willem et al. 2002; Bader et al. 2005; Bose et al. 2006). However, type IV collagen and, if present, nidogens were still found to accumulate in most basement membranes. Thus there appear to be laminin-dependent binding interactions that exist outside of the bonds of the laminin-nidogen type-IV collagen central axis. These, however, are likely to be of much lower affinity (Willem et al. 2002). The early lethality suggests that nidogen and its binding to laminin becomes more particularly important for basement membrane stabilization during late embryogenesis and adult life when increased mechanical stresses arise.

\section{Agrin and Perlecan Provide Collateral Linkage to Cell Surfaces}

A high-affinity binding interaction was discovered among the upper coiled-coil segment of the $\gamma 1$ subunit with the amino-terminal NtA domain of agrin (Denzer et al. 1998; Kammerer et al. 1999). The LG domains of agrin were also found to bind strongly to $\alpha$-dystroglycan and to sulfatides (Gesemann et al. 1998). In the case of the neural agrin splice variant released by the peripheral nerve terminus, the interaction likely helps retain agrin within the basement membrane, enhancing its activity in neuromuscular junction assembly and/or stabilization (Meier et al. 1997; Lin et al. 2008). In the case of the more widely expressed nonneural ("muscle") agrin splice variants, the interactions appear to allow agrin to serve as a stabilizing collateral link among laminin and the cell surface and underlying cytoskeleton (Moll et al. 2001; McKee et al. 2009). Collateral linkage may be particularly important for adhesion of laminins (notably Lm-411) that bind poorly to integrins and dystroglycan. The binding provided by agrin has been exploited to substantially repair the sarcolemmal basement membrane and dystrophic muscle phenotype in an $\alpha 2$ laminindeficiency state (Moll et al. 2001). Perlecan can likely play a related role as agrin. It binds to nidogen (that in turn binds to laminin) through an interaction among domain IV and the nidogen G2 domain, and binds to the cell surface through interactions among the LG domains and $\alpha$-dystroglycan, sulfatides, and the $\alpha 2 \beta 1$ integrin (Friedrich et al. 1999; Hopf et al. 1999; Hopf et al. 2001; Bix et al. 2004).

\section{Type IV Collagen Forms a Covalently} Cross-Linked Polymer That Stabilizes the Basement Membrane

There are three type IV collagen heterotrimers, each a long $(\sim 400 \mathrm{~nm})$ triple-helical molecule with kinks along its length and terminating in a globular (NC1) domain (Fig.1). The most common variant, found in nearly all basement membranes, consists of two $\alpha 1$ subunits and one $\alpha 2$ subunit $\left(\alpha 1_{2} \alpha 2[\right.$ IV] $)$. Type IV collagen trimers have been found to self-assemble to form a branching network one to several chains thick consisting of NC1-dimers, amino-terminal tetramers (7S domain), and lateral associations (Timpl et al. 1981; Yurchenco and Furthmayr 1984; Siebold et al. 1987; Yurchenco and Ruben 1987) (Fig. 3). The structure of the $\mathrm{NC1}$ domain is such that it presents a flat face to its partner for dimerization and becomes stabilized through an unusual covalent linkage between $\alpha 1$ Met93 and Hyl211 (Sundaramoorthy et al. 2002; Than et al. 2002). Although knockout of the genes coding for the $\alpha 1$ and $\alpha 2$ subunits was not found to prevent basement membrane assembly in most tissues, it led to lethality in mice at E10.5-11.5 because of an 
apparent loss of basement membrane stability in different tissues including Reichert's membrane (Poschl et al. 2004). Analysis of point mutations leading to reductions of type IV collagen because of faulty chain assembly (hypomorph) have been associated with development of porencephaly and hemorrhagic stroke, suggesting a critical role of type IV collagen in the stabilization of the microvasculature (Gould et al. 2005; Breedveld et al. 2006; Gould et al. 2006; Gould et al. 2007).

The other type IV collagen variants, found in the glomerular basement membrane (GBM), Bowman's capsule, neuromuscular junction, and other locations are assembled as $\alpha 3 \alpha 4 \alpha 5$ [IV] and $\alpha 5_{2} \alpha 6[\mathrm{IV}]$ heterotrimers respectively. Polymers of type IV collagen consisting of the $\alpha 3 \alpha 4 \alpha 5$ [IV] subunits appear to form particularly stable networks by virtue of the formation of additional reducible cross-links among the collagen chains (Gunwar et al. 1998). This stabilization is likely important for GBM architecture and function. In addition, the $\alpha 3 \mathrm{NC} 1$ domain has been found to be a ligand for $\alpha \mathrm{v}$ and $\alpha 3$ integrins (Maeshima et al. 2000; Petitclerc et al. 2000; Borza et al. 2006). When mutations develop in the genes coding for these subunits, leading to development of a GBM containing only $\alpha 1_{2} \alpha 2$ [IV] collagen, the GBM is thought to be destabilized leading to development of Alport syndrome (Hudson et al. 2003). The disease is seen as progressive renal failure with hematuria and proteinuria, reflecting a breakdown of the GBM filter barrier in which the GBM develops splits and laminations.

\section{Proteoglycans and Growth Factor Tethering}

The heparan sulfate proteoglycans agrin, perlecan, and type XVIII collagen have the potential to tether and accumulate growth factors (Iozzo et al. 2009). Such heparin-binding factors include fibroblast growth factors (FGF, especially FGF-2), transforming growth factor- $\beta$ (TGF $\beta$ $1,2)$, bone morphogenic proteins (BMPs-2,4,7), glial-derived neurotrophic factor (GDNF), vascular endothelial growth factors (VEGF), heparin-binding epidermal growth factor (HB-EGF), and neuregulin (Plotnikov et al. 1999; Li and
Loeb 2001; Rider 2006). In addition, the core protein of perlecan (domains III - IV) binds directly to FGF7 and platelet-derived growth factor (PDGF) (Gohring et al. 1998; Mongiat et al. 2001). In genetic studies, basement membranedependent growth factor interactions have been implicated in limb morphogenesis and probably play similarly important roles in the development of many tissues (Bose et al. 2006).

A model for the activation of growth factor receptor tyrosine kinases (RTKs) is that the ligand, or ligand pair, binds to its RTK to induce receptor dimerization that enables autophosphorylation of the receptor cytoplasmic tail and that results in downstream signaling. In the case of the FGF receptors that bind FGF2 and that have been crystallized as a complex, formation of an active complex has been found to be greatly facilitated by heparin and heparan sulfates that interact with both FGF and receptor (Schlessinger et al. 2000). Heparin analogs have been shown to block the mitogenic effect and ligand-receptor binding for PDGF, TGF $\beta$, and VEGF, implicating a similar role for heparan sulfates (Hamma-Kourbali et al. 2001). Integrins have been found to act in concert with growth factor receptors (EGFR, PDGFR, and FGFR), inducing the accumulation of the RTKs to clustered ligand-occupied integrins and enhancing the phosphorylation of both RTK and the common downstream MAP kinase pathway (Miyamoto et al. 1996). Basement membranes may be particularly well suited to mediate such synergism through the presence of macromolecules that possess both heparan sulfate chains and integrin ligands. The latter effect may furthermore be enhanced by the length of the heparan sulfate chains (Paulsson et al. 1987) given the finding that long chains have the potential to engage multiple FGF/receptor complexes to enhance signaling (Paulsson et al. 1987; Harmer et al. 2006).

\section{Basement Membrane-Stromal Interface Collagens}

Type XVIII collagen is a heparan sulfate proteoglycan that is concentrated at or near the interface of the basement membrane and stroma 
(reviewed in Marneros and Olsen 2005). Enzymatic cleavage of its NC1 domain releases the endostatin fragment that has been found to inhibit angiogenesis in various culture systems and that has been considered a reagent for reduction of tumor size. Mutations of the gene for type XVIII collagen are a cause of Knobloch syndrome, characterized by vitreoretinal degeneration and occipital encephalocele. Type $X V$ collagen is a nonfibrillar collagen with multiple interruptions of the gly-x-y sequence and with attachments to both heparan sulfate and chondroitin sulfate chains (Myers et al. 1996; Myers et al. 2003). Found at the basement membrane/stromal interface, it is also thought to serve as a link to the stroma (Myers et al. 1997). Type VI collagen is a widely expressed component that is particularly important for skeletal muscle function (reviewed in Lampe and Bushby 2005). The collagen, composed of three different subunits, was found to selfassemble through a staggered disulfide-stabilized tetramer intermediate to microfibrils (Furthmayr et al. 1983; Zhang et al. 2002). Type VI collagen binds under in vitro conditions to type IV collagen and type I collagen, linking the basement membrane to the adjacent stroma (Bonaldo et al. 1990; Kuo et al. 1997). It also binds to perlecan. Mutations in the genes coding for the three collagen chains cause Bethem myopathy and Ullrich congenital muscular dystrophy.

\section{Other Basement Membrane Components}

Netrins (discovered as Unc6 in Caenorhabditis elegans) represent a family of secreted ECM proteins found both within and outside the central nervous system, affecting axonal guidance, interneuronal migration, vasculogenesis, and branching morphogenesis (reviewed in Yurchenco and Wadsworth 2004; Cirulli and Yebra 2007). Each netrin molecule is composed of a laminin-type LN domain followed by three LE repeats and a carboxy-terminal domain unrelated to laminin. Vertebrate netrin-1 is a chemotropic factor that guides axons during spinal cord development (Kennedy et al. 1994). Axonal guidance of netrins is mediated by receptors of the UNC5 family and DCC (deleted in colorectal cancer) and neogenin family. Netrin-1 also was found to be a ligand for integrin $\alpha 3 \beta 1$ with the interaction implicated in neuronal migration (Stanco et al. 2009). Netrin-4, a more distantly related member with greatest homology with the $\beta$-laminin short arm (Yin et al. 2000) and widely expressed in basement membranes of developing tissues, has been found to inhibit laminin-111 polymerization, evidence for a binding interaction with the laminin LN domains (Schneiders et al. 2007).

Nephronectin, a specific ligand for the $\alpha 8 \beta 1$ integrin, was identified in developing kidney in the basement membrane zone of the ureteric bud epithelium (Brandenberger et al. 2001). Specificity and affinity of binding has been found to depend on a primary RGD sequence and an auxiliary carboxy-terminal LFEIFEIER sequence (Sato et al. 2009). Analysis of the renal agenesis and hypoplasia that develops in nephronectin-deficient mice supported a critical morphogenic role of the ligand-receptor interaction with evidence that nephronectin ligation to the mesenchymal integrin stimulates transient secretion of mesenchymal GDNF (glial derived neurotrophic factor) that recruits the bud to the mesenchyme and promotes its branching (Linton et al. 2007). Nephronectin is also expressed in other embryonic and adult tissues that include skin, eye, heart and lung where it may play related instructive roles $(\mathrm{Hu}-$ ang and Lee 2005).

Usherin (type $a$ and $b$ ) refers to two proteins obtained by alternative splicing of the USH2A gene. The shorter (a) version consists of a tandem array of laminin LG, laminin LN, ten LE repeats, and four fibronectin type 3 repeats. The longer version contains additional fibronectin repeats with distal transmembrane and cytoplasmic domains (reviewed in Reiners et al. 2006). Its absence is a cause of Usher syndrome type $2 \mathrm{~A}$ characterized by hearing impairment and retinitis pigmentosa. The protein has been detected in basement membranes of the cochlea, retina, and other tissues (Bhattacharya et al. 2002). It has been found to bind to type IV collagen and fibronectin through its LE domains (Bhattacharya et al. 2004; Bhattacharya and Cosgrove 2005). 
Papilin, an alternatively spliced glycoprotein, was first identified in Drosophila (Campbell et al. 1987). It has an amino-terminal cassette of domains similar to the carboxyterminal ADAMTS subgroup of secreted, matrix-associated metalloproteinases (Kramerova et al. 2000). Papilins are primarily found in basement membranes and are essential for fruit fly and nematode development.

\section{EXTRACELLULAR MATRICES AS SOLID-PHASE AGONISTS}

Basement membranes, like other ECMs, are solid-phase agonists. Evidence has emerged that ligand-bearing polymers transmit information to cells not simply on the basis of ligand composition and their bound-receptors, but on the basis of the mechanical (viscoelastic) properties of the polymer itself. Cell-interactive materials range from soft gels (such as those formed by laminins) to rigid substrates such as bone and ECM-coated glass and plastic. Polymer contributions are mediated through integrins with substrate stiffness stimulating integrin expression and activation (Katsumi et al. 2004; Katsumi et al. 2005).

Elucidation of the mechanical contributions of polymers, using ligand-modified acrylamide and alginate gels, has been used to evaluate the effects of polymer viscosity distinct from ligand density. Using this approach, the organization of actin and myosin in $\mathrm{C} 2 \mathrm{C} 12$ myotubes to create striated myofibrils was found to depend on substrate stiffness in which an intermediate gel viscosity was optimal for differentiation (Engler et al. 2004). Furthermore, gel stiffness was found to drive alternate differentiation pathways in mesenchymal stem cells such that soft gels favored a neurogenic path, semi-stiff gels favored a myogenic path, and very stiff gels favored an osteogenic path. In a study of mesenchymal cell behavior using RGD-coupled alginates, it was found that matrix stiffness regulated integrin binding, again optimal at intermediate levels of stiffness (Huebsch et al. 2010).

Basement membranes contain gel-like polymers in which viscosity increases as a function of laminin and/or type IV collagen concentration (Yurchenco and Furthmayr 1984; Yurchenco et al. 1990). Laminin-111 gels have been found to promote glandular differentiation and milk production in cultured mammary gland epithelial acini (Streuli et al. 1991; Streuli et al. 1995). Using atomic force microscopy to measure laminin-111 and laminin/ collagen I substrata resistance to deformation, it was recently found that mammary cell production of casein depended both on the presence of a soft gel as well as on laminin signaling (Alcaraz et al. 2008).

\section{EARLY MORPHOGENESIS}

In mammals, the first basement membranes to appear are those of the pre-implantation embryonic plate and Reichert's membrane. Assembly of these ECMs requires laminin heterotrimers secreted by the visceral (laminins-111 and -511) and parietal endoderm (laminin111) that have subsequent profound effects on the adjacent inner cell mass composed of embryonic stem (ES) cells (Miner and Yurchenco 2004). These effects have been examined in cultured ES cells allowed to differentiate into embryoid bodies (EBs) in suspension culture. Laminins are required for epiblast polarization, EB cavitation, and protection of adhered cells from apoptosis (Murray and Edgar 2000). Laminin-111, in a process dependent on polymerization and adhesive activities that map to the LN and LG domains, respectively, was found to induce polarization of laminin $\gamma 1$-null ES cells (Li et al. 2002). $\beta 1$-integrins, dystroglycan, integrin adaptor proteins, and utrophin were noted to be recruited to the basal side (where the basement membrane assembles) of developing epithelia, possibly representing the basis of the polarization induction ( $\mathrm{Li}$ et al. 2003b). Cell polarization was not found to have an absolute requirement for either $\beta 1$-integrins or for dystroglycan; however, efficiency of the process was diminished by loss of either. Furthermore, absence of either $\beta 1$-integrin or dystroglycan was associated with increased epiblast apoptosis. Dystroglycan expression was increased in the absence of integrin, whereas integrin 
expression remained constant in the absence of dystroglycan. Expression of basement membrane components was elevated in the absence of dystroglycan (producing a thick basement membrane) or laminin through what appears to be loss of laminin LG-integrin mediated regulation. These findings suggested the existence of compensatory integrin/dystroglycan/ECM mechanisms for epiblast development ( $\mathrm{Li}$ et al. 2002). Mediators of polarization downstream of the basement membrane were found to include integrin-linked kinase, PINCH-1, Rac1 and Cdc42 and kindlin-2 (Sakai et al. 2003; Li et al. 2005a; Wu et al. 2007; Montanez et al. 2008; He et al. 2010).

\section{GLOMERULAR DEVELOPMENT AND FILTRATION}

Kidneys are organs enriched in epithelial and vascular basement membranes in which a wide variety of laminins and type IV collagens are expressed in a developmentally- and sitespecific manner (Miner and Sanes 1994; Miner et al. 1997). The glomerulus contains ECMs associated with epithelial (podocyte, cells of Bowman's capsule), vascular (capillary tuft), and mesangial cells. The thick GBM was found to be fused from developing capillary and podocyte precursor structures (Abrahamson 1985; Abrahamson 1987). During early glomerular organization (S-phase) laminin $\alpha 5, \alpha 4, \alpha 1$, and $\beta 1$ subunits and type IV collagen $\alpha 1$ and $\alpha 2$ chains are present. By maturity, the laminin $\beta 2$ subunit replaced $\beta 1$ with $\alpha 5$ now the major $\alpha$-subunit, and type IV collagen $\alpha 3, \alpha 4$, and $\alpha 5$ chains, produced by the podocytes, largely supplanting the embryonic $\alpha 1$ and $\alpha 2$ chains (Miner and Sanes 1994; Miner et al. 1997; Abrahamson et al. 2009). Failure of the laminin $\beta 1$ to $\beta 2$ transition was found to result in a normalappearing GBM associated with proteinuria whereas failure of replacement of laminin $\alpha 1$ by $\alpha 5$ was found to result in a failure of the glomerular tuft to develop within Bowman's space and a failure of normal organization of the glomerular cell types, effects likely caused by absence of $\alpha 5$-laminin receptor interactions (Noakes et al. 1995b; Miner and Li 2000;
Moulson et al. 2001). The unique receptorbinding activities within the laminin $\alpha 5$ subunit, not found in the laminin $\alpha 1$ compensating subunit and required for glomerular vascularization, were localized to the LG1-3 domains that mediate integrin $\alpha 3 \beta 1$ and Lutheran receptor binding (Kikkawa et al. 2002; Kikkawa and Miner 2006).

The mature glomerular capillary wall provides a filtration function in which large and negatively charged blood macromolecules are selectively prevented from entering the urinary space ("permselectivity"). At the ultrastructural level, the capillary endothelium adjacent to the GBM is fenestrated whereas the epithelium on the urinary side is composed of interdigitating foot processes separated by thin diaphragmatic slits. Thus, at least two extracellular barriers exist that may affect the passage of proteins from the vascular space to the urinary space, i.e., the GBM and the slit diaphragms. In the nephrotic syndrome, resulting from a variety of diseases that include diabetic nephropathy, massive amounts of protein accumulate in the urine. Proteinuria is commonly accompanied by foot process effacement, altering filtration barrier architecture. Studies of GBM penetration by different-sized dextrans in rats provided early evidence that the basement membrane, rather than the slit, acts as the primary filtration barrier (Caulfield and Farquhar 1974). This was seemingly supported by the observation of the proteinuria that occurred following inactivation of either the gene (Lamb2) coding for the laminin $\beta 2$ unit (a subunit found in kidney almost exclusively in the GBM) or podocyte-specific inactivation of the Lama5 gene (Noakes et al. 1995b; Goldberg et al. 2010). In humans, mutations of the Lamb2 gene cause Pierson syndrome, a disorder of congenital nephrosis and mesangial sclerosis associated with eye and (sometimes) neuromuscular junction abnormalities (Zenker et al. 2004; Wuhl et al. 2007). The GBM filtration model, however, was challenged by the discovery that absence of nephrin, a structural component of the slit diaphragm, also causes the nephrotic syndrome (Kestila et al. 1998; Wartiovaara et al. 2004). It was suggested that the slit diaphragm serves as 
the primary permselective barrier with the GBM mutations affecting filtration alterations through an indirect effect (e.g., podocyte effacement) (Deen 2004; Wartiovaara et al. 2004). However, subsequent evidence that the proteinuria induced by absence of the laminin- $\beta 2$ subunit of the murine GBM precedes podocyte effacement argued against this interpretation (Jarad et al. 2006). Although it seems likely that the architectures of the GBM and the slit diaphragm both contribute to glomerular filtration, their different roles still remain to be fully elucidated.

Another aspect of permselectivity is macromolecular net charge. The polyanionic heparan sulfate chains have been thought to be responsible for the charge-sieving properties of the glomerulus in which acidic macromolecules are preferentially excluded from urine (Groggel et al. 1987; Groggel et al. 1988). However, recent genetic evidence in which the principal GBM HSPG agrin was selectively knocked out in mouse podocytes revealed that reduction of GBM heparan sulfates did not alter chargeselectivity (Harvey et al. 2007). One possibility is that the glycocalyx of either the endothelium or podocytes is responsible for charge-sieving.

\section{EPIDERMAL-DERMAL JUNCTION: STABLE ADHESION AND CELL MIGRATION}

The proteins of the epidermal-dermal junction illustrate one of the key roles of basement membranes that lie among epithelium and stroma, i.e., the formation of stable linkages through hemidesmosomes (HDs) that protect the tissue from disruptive shear forces and prevent blistering. Laminin-332, enriched in keratinocyte basement membranes, is the predominant laminin that binds to the $\alpha 6 \beta 4$ integrin and (less strongly) to BP180. The laminin-specific $\alpha 6 \beta 4$ integrin has an unusually long $\beta$-subunit tail that allows it to bind to HD plectin that links keratin. In the basement membrane zone, a bond is formed among laminin-332 and type VII collagen of the stromal anchoring fibrils (Rousselle et al. 1997; Litjens et al. 2006; Nishiuchi et al. 2006). Thus laminin 332 forms a crucial link among the cell HD and the stromal anchoring fibrils. Knockout of the Lama3 gene was lethal at the neonatal stage and resulted in loss of $\alpha 6 \beta 4$-mediated adhesion (Ryan et al. 1999). Loss of this laminin linkage through mutations in any of the three subunits results in blistering diseases of skin in which a split develops through the basement membrane itself (reviewed in Mitsuhashi and Hashimoto 2003).

Following wounding, keratinocytes detach from anchoring HDs and migrate to reestablish epithelial continuity. This process is thought to involve HD structural disassembly and to depend on proteolytic enzymes that remove the $\alpha 3$ LG4-5 globules and proximal $\gamma 2$ short arm, promoting switching among stable anchorage and migration (Carter et al. 1991; Rousselle et al. 1991; Marinkovich et al. 1992a; Marinkovich et al. 1992b; Giannelli et al. 1997; Koshikawa et al. 2005). All of the laminins, with the exception of $\alpha 1$-laminins, undergo proteolytic cleavage of the LG domains and/or short arm. Laminin-3A32, the most heavily processed of all of the known laminins, can be cleaved by MT1-MMP and MMP-2 in the $\gamma 2 \mathrm{LEb}$ domain, by plasmin, BMP-1, MT1-MMP and other enzymes in the $\gamma 2 \mathrm{LEa}$ domain, by plasmin, MT1MMP and other enzymes among $\alpha 3$ LG3 and 4, and by MT1-MMP in the $\beta 3 \mathrm{LE}$ domain (reviewed in Sugawara et al. 2008). Cleavage of the $\gamma 2$ short arm by MT1-MMP or MMP-2 appears to expose a cryptic site that promotes migration, possibly by releasing an EGF-containing fragment that binds to the EGF receptor (Giannelli et al. 1997; Schenk et al. 2003). On the other hand, cleavage of the $\alpha 3 L G$ domains has been proposed to change laminin-3A32 from one in an anchorage-promoting mode to one in a migration-mode (Goldfinger et al. 1998). Although laminin-511 has been shown to be crucial for hair follicle development, its role in cutaneous morphogenesis and maintenance is less clear (Li et al. 2003a). The predominant integrin that interacts with this laminin is thought to be $\alpha 3 \beta 1$; however, the laminin also interacts with $\alpha 6 \beta 1$ and $\alpha 6 \beta 4$. Despite the potential for interactions with $\alpha 6 \beta 4$, the principal hemidesmosomal interaction is with laminin-332. Laminin-511 instead appears to provide much of the interaction among 
P.D. Yurchenco

keratinocyte and basement membrane outside of the hemidesmosomes. One property of laminin-511 might be one of modulating cell adhesion strength following short arm cleavage (Bair et al. 2005).

\section{STABILIZATION OF THE SARCOLEMMA}

The principal laminin of the skeletal muscle sarcolemmal basement membrane is Lm-211, with lesser amounts of $\alpha 4, \alpha 5$, and $\beta 2$ laminins. Mutations adversely affecting the amount or function of the laminin $\alpha 2$ subunit result in congenital muscular dystrophy in mice and humans (type MDC1A). The sarcolemma is rich in dystroglycan, a glycoprotein whose $\alpha$-subunit binds to the LG domains of laminins, agrin, and perlecan and whose $\beta$-subunit is a transmembrane protein that binds to dystrophin and utrophin. Mutations of the glycosyl-transferases thought to mediate the O-mannosyl glycosylation of $\alpha$-dystroglycan, required for LG domain binding, result in a form of congenital muscular dystrophy collectively referred to as the " $\alpha$-dystroglycanopathies." These include Walker-Warburg syndrome and muscle-eye-brain disease. O-mannosyl carbohydrates have been found only in $\alpha$-dystroglycan and are unusual in that the mannose is added to dystroglycan in the endoplasmic reticulum from a dolichol-phosphate intermediate (Maeda and Kinoshita 2008; Lefeber et al. 2009). The principal O-mannosyl oligosaccharide of dystroglycan is a linear tetrasaccharide (NeuNAc- $\alpha-2,3-$ Gal- $\beta-1,4-G l c N A c-$ $\beta-1,2-$ Man) attached to serine or threonine residues within the central neck domain. A surprising recent set of findings is that the mannose residue can possess an internal phosphoryl linkage insensitive to alkaline phosphatase digestion, that formation of the modified mannose requires the putative glycosyl-transferase LARGE, and that LG-domain binding requires the presence of the phosphoryl group (YoshidaMoriguchi et al. 2010). This carbohydrate modification may help explain why dystroglycan, which does not require the terminal sialic acid for binding, interacts with many of the charged lysine and arginine residues in the LG4/5 domains of the laminin $\alpha 1$ and $\alpha 2$ subunits involved in heparin and sulfatide binding (Wizemann et al. 2003; Harrison et al. 2007).

Dystroglycan and integrin connect the sarcolemmal basement membrane to the underlying actin cytoskeleton. In muscle, the dystroglycan-dystrophin linkage appears to be particularly important for muscle contraction that exerts strong shear forces to the sarcolemma and the connections among muscle fibers. Thus the degree of sarcolemmal damage resulting from loss of dystroglycan binding during muscle contraction/relaxation is much greater compared with integrin, causing detachment of the basement membrane from the adjacent plasma membrane (Han et al. 2009). The basement membrane is also attached to the adjacent interstitial collagenous stroma. This role (discussed earlier) is provided by type VI collagen that binds to both basement membrane components and to interstitial collagens.

Overall one can trace a continuous set of linkages extending from the cytoskeleton to dystroglycan to basement membrane to the stromal collagen that is required to stabilize the sarcolemma. Mutations affecting any of the key links (dystrophin, dystroglycan-binding to basement membrane, laminin-211, type VI collagen) result in a muscular dystrophy. One suspects that a mutation affecting type IV collagen or nidogen expression, if it were not embryonic/neonatal lethal, would similarly result in a dystrophic state.

\section{PERIPHERAL NERVE AXONAL ENVELOPMENT AND MYELINATION}

During morphogenesis of the peripheral nerve, neural crest-derived Schwann cell precursors assemble basement membranes, proliferate and extend cytoplasmic processes that sequester, envelop and myelinate single axons in a process called "radial sorting" (Webster et al. 1973; Jessen and Mirsky 2005). During this process, immature Schwann cells assemble basement membranes on their abaxonal surfaces. Mutations that prevent expression of the laminin $\gamma 1$, $\alpha 2$, and $\alpha 4$ subunits, or that remove the laminin $\alpha 2-\mathrm{LN}$ domain (dy2J), result in radial sorting defects (Sunada et al. 1995a; Miyagoe et al. 
1997; Wallquist et al. 2005; Yang et al. 2005). The Lm $\alpha 2$ deficient mice provide models of the nerve pathology seen in human MDC1A congenital muscular dystrophy. The deficiency state phenotype was found to be corrected by transgenic expression of the homologous laminin $\alpha 1$ subunit, a genetic rescue that was only partially dependent on the presence of the LG4-5 domains (Gawlik et al. 2006; Gawlik et al. 2010).

The Lm $\alpha 4$ deficiency state is more difficult to understand. Laminin 411 binds poorly to its integrins ( $\alpha 6 \beta 1, \alpha 7 \beta 1$ ), poorly to dystroglycan, and lacks an $\alpha \mathrm{LN}$ domain with its associated activities. It is possible that laminin-411 partially disrupts the laminin-211 polymer through interfering interaction of its two LN domains, altering the viscoelastic state and signaling potential. Alternatively, the weak receptor binding may mediate a unique set of signals. Finally, laminin-411 may interact with a novel receptor.

Schwann cell-specific inactivation of the genes coding for $\beta 1$-integrin, Racl, and integrin-linked kinase (ILK) were similarly found to cause radial sorting defects whereas inactivation of the genes coding for $\beta 4$-integrin and dystroglycan (both proteins are expressed late in nerve development) were found to be important for myelin stability and nodal morphogenesis (Feltri et al. 2002; Benninger et al. 2007; Nodari et al. 2008; Pereira et al. 2009). An evolving but incomplete model holds that laminin (or basement membrane) ligation of $\beta 1$ integrins promotes lammellipodial extension and axonal interdigitation through alterations of the activated state of Rac1, Cdc42 and Rho/ Rho kinase. Laminins can affect both Schwann cell proliferation and process extension and proliferation whereas $\beta 1$-integrins affect only the former (Yu et al. 2005; Yu et al. 2009).

\section{BASEMENT MEMBRANES IN THE DEVELOPING BRAIN}

In the embryonic mammalian brain, neuroectodermally derived glia become elongated bipolar cells that extend from the ventricular (apical) to the pial (basal) surface, the latter contacting the pial basement membrane through glial endfeet. These cells can give rise to neurons and affect their fate. Of note, the basal cell processes of these radial glial cells appear to act as a guide for the migration of newly formed neurons in the ventricular zone to the pia, leading to the formation of cell layers (reviewed in Kosodo and Huttner 2009). Mutations affecting expression of laminins, the nidogen-binding site in the laminin $\gamma 1$ subunit (Lm $\gamma 1 \Delta \mathrm{LEb} 3$ ), perlecan, $\alpha 6$ and $\beta 1$-integrins, dystroglycan, focal adhesion kinase, and integrin-linked kinase have been found to result in separation of glial cells from the basement membrane because of apparent loss of ECM integrity, and defects of neuronal cell migration and cell layer formation leading to cobblestone-type lissencephaly (Georges-Labouesse et al. 1998; Costell et al. 1999; Graus-Porta et al. 2001; Halfter et al. 2002; Moore et al. 2002; Beggs et al. 2003; Niewmierzycka et al. 2005). Further analysis of the Lm $\gamma 1 \Delta \mathrm{LEb} 3$ null, integrin $\alpha 6$-null and perlecan-null mice revealed that radial glial contact was important for neuronal migration and cortical layer formation but not for proliferation or neurogenic capacity (Haubst et al. 2006). The phenotypic similarity resulting from loss of structural proteins and receptors raises an interesting question concerning the relationship among structural integrity of the basement membrane, stable anchorage to the cell and signaling in the maintenance of the brain function.

\section{VASCULAR BASEMENT MEMBRANES}

Vascular endothelial cells rest on a basement membrane enriched in $\alpha 4$ - and $\alpha 5$ laminins. In the pancreas, microvessels are recruited by islet cell release of VEGF-A. It is reported that the microvascular basement membranes enable insulin gene expression and promote $\beta$-islet cell proliferation, exerting their effect through laminin and $\beta 1$ integrin (Nikolova et al. 2006). In the central nervous system, the postcapillary venule is a site of lymphocyte extravasation. It has been found that T-lymphocyte emigration is promoted by laminin $\alpha 4$ and prevented by laminin $\alpha 5$, an effect deduced to depend on the binding of $\alpha 4$ laminin to the $\alpha 6 \beta 1$ integrin 
(Wu et al. 2009). The integrin specificity is somewhat surprising given that $\alpha 5$-laminins, unlike $\alpha 4$-laminins, are strong substrates for $\alpha 6 \beta 1$.

Basement membranes of the microvasculature present a barrier to the transmigration (diapedesis) of leukocytes during immune surveillance and inflammation. Cancer cells must cross vascular and nonvascular basement membranes during metastases. Transmigration is also seen during embryogenesis, for example gonadal anchor cell invasion in the developing nematode that serves as a model system to study the mechanisms underlying the process (Sherwood et al. 2005). The basement membrane scaffold is a tight covalently cross-linked mesh formed by laminin and type IV collagen polymers that is bridged by nidogens and to which are bound other components and it is unlikely that a cell could squeeze through interstices of the order of $50 \mathrm{~nm}$ or less. Nonetheless, cells constantly migrate across basement membranes (reviewed in Rowe and Weiss 2008). The process has long been thought to require local cell degradation of the basement membrane with matrix metalloproteinases (especially MTMMPs) and other enzymes. However, transmigration might also occur through mechanisms independent of proteolytic digestion (Huber and Weiss 1989). Cellular invadopodia may either transiently disrupt covalent and noncovalent linkages with local matrix disassembly or somehow breach small structural imperfections in the barrier.

\section{CONCLUDING REMARKS}

Many of the basement membrane-relevant discoveries made in the past few decades have depended on the convergence of diverse disciplines ranging from biochemistry to genetics to bioengineering and on technological innovations such as the manipulation of recombinant glycoproteins, the development of physiologically relevant in vitro models, and mammalian and invertebrate/fish genetics. New contributions of approaches and techniques are likely to continue as the field matures. In looking toward the future, one can identify several possible directions.
1. Basement membrane proteins are composed of multiple domains, many of which are glycosylated. Functional activities have been assigned only to a small fraction of these domains. Although some of the domains, particularly those in repeats, likely act as structural spacers (e.g., to separate the laminin polymerization domains), one suspects that others have as-yet-undiscovered roles. A more exhaustive search for domain-specific interactions, especially those of relatively high affinity, may be accomplished by using high-throughput analyses such as those of proteomics and glycomics.

2. Although the discovery of genetic disorders has taught us much in recent years, it is evident that basement membranes are involved in the pathogenesis of more common disorders such as diabetes mellitus, hypertension, and cancer progression. Insights into the mechanistic role played by the extracellular matrices in these diseases will help us to better understand disease progression and possible treatments. One such disorder is diabetes mellitus, in which basement membranes of the kidney, retina, and peripheral nerves become thickened as part of the evolution of the microvascular sequelae of chronic hyperglycemia. The thickening, which has long been suspected to be associated with a paradoxical alteration of permselectivity, may be a consequence of increased expression of laminin and other components.

3. Cancer invasion and metastasis is another relevant clinical area. Not only must malignant cells cross basement membrane barriers to spread, but tumors that seed at new sites must recruit a basement membrane-containing vascular supply to expand. There has been a strong clinical interest in identifying inhibitors of angiogenesis to prevent tumor growth (Folkman 2004). Potentially useful inhibitors are the NC1 domains of type XVIII collagen (endostatin) and type IV collagen (Nyberg et al. 2005; Folkman 2006; Borza et al. 2006). These proteins may act, at least in part, through their integrin-binding activity. It may also be possible 
to express enzymes or other factors that accumulate in targeted basement membranes such as those of the microvasculature through specific binding sites in laminins or other components such that they impart desired activities such as the degradation of heparan sulfate chains to prevent growth factor binding and receptor activation. At a more general level, research into the role of basement membranes in vascular development and functions has been fairly limited and represents a clinically relevant area in need of more intensive study.

4. Stem cells, both embryonic and adult, are under investigation for their potential use in the generation of regenerative tissues. Basement membranes have been found to affect stem cell as well as tissue behavior and may play useful roles in driving stem cells down differentiation pathways and in the maintenance of biological activity and stability of engineered tissues. It has recently been discovered, for example, that recombinant laminin-511 is an outstanding substrate to maintain mouse and human stem cells in a pluripotent state, whereas the laminin in a more complex environment has been reported to drive pancreatic differentiation (Domogatskaya et al. 2008; Higuchi et al. 2010; Rodin et al. 2010). Basement membrane components are also being used to modify the surface properties of biomimetic materials for use in tissue engineering, e.g., nerve conduits (reviewed in von der Mark et al. 2010).

In conclusion, we have learned some of the properties and functions of basement membranes and their components. Future advances seem likely to depend on an increasingly indepth understanding of structure-function relationships in the context of cellular and organismal biology.

\section{ACKNOWLEDGMENTS}

This review was supported by a grant (R37DK36425) from the National Institutes of Health.

\section{REFERENCES}

Abrahamson DR. 1985. Origin of the glomerular basement membrane visualized after in vivo labeling of laminin in newborn rat kidneys. J Cell Biol 100: 1988-2000.

Abrahamson DR. 1987. Structure and development of the glomerular capillary wall and basement membrane. Am J Physiol 253: F783-F794.

Abrahamson DR, Hudson BG, Stroganova L, Borza DB, St. John PL. 2009. Cellular origins of type IV collagen networks in developing glomeruli. J Am Soc Nephrol 20: $1471-1479$.

Alcaraz J, Xu R, Mori H, Nelson CM, Mroue R, Spencer VA, Brownfield D, Radisky DC, Bustamante C, Bissell MJ. 2008. Laminin and biomimetic extracellular elasticity enhance functional differentiation in mammary epithelia. EMBO J 27: 2829-2838.

Aumailley M, Bruckner-Tuderman L, Carter WG, Deutzmann R, Edgar D, Ekblom P, Engel J, Engvall E, Hohenester E, Jones JC, et al. 2005. A simplified laminin nomenclature. Matrix Biol 24: 326-332.

Bader BL, Smyth N, Nedbal S, Miosge N, Baranowsky A, Mokkapati S, Murshed M, Nischt R. 2005. Compound genetic ablation of nidogen 1 and 2 causes basement membrane defects and perinatal lethality in mice. $\mathrm{Mol}$ Cell Biol 25: 6846-6856.

Bair EL, Chen ML, McDaniel K, Sekiguchi K, Cress AE, Nagle RB, Bowden GT. 2005. Membrane type 1 matrix metalloprotease cleaves laminin-10 and promotes prostate cancer cell migration. Neoplasia 7: 380-389.

Barresi R, Campbell KP. 2006. Dystroglycan: From biosynthesis to pathogenesis of human disease. J Cell Sci 119: 199-207.

Beck K, Dixon TW, Engel J, Parry DA. 1993. Ionic interactions in the coiled-coil domain of laminin determine the specificity of chain assembly. J Mol Biol 231:311-323.

Beggs HE, Schahin-Reed D, Zang K, Goebbels S, Nave KA, Gorski J, Jones KR, Sretavan D, Reichardt LF. 2003. FAK deficiency in cells contributing to the basal lamina results in cortical abnormalities resembling congenital muscular dystrophies. Neuron 40: 501-514.

Benninger Y, Thurnherr T, Pereira JA, Krause S, Wu X, Chrostek-Grashoff A, Herzog D, Nave KA, Franklin RJ, Meijer D, et al. 2007. Essential and distinct roles for cdc42 and racl in the regulation of Schwann cell biology during peripheral nervous system development. J Cell Biol 177: 1051-1061.

Berrier AL, Yamada KM. 2007. Cell-matrix adhesion. J Cell Physiol 213: 565-573.

Bhattacharya G, Cosgrove D. 2005. Evidence for functional importance of usherin/fibronectin interactions in retinal basement membranes. Biochemistry 44: 11518-11524.

Bhattacharya G, Kalluri R, Orten DJ, Kimberling WJ, Cosgrove D. 2004. A domain-specific usherin/collagen IV interaction may be required for stable integration into the basement membrane superstructure. J Cell Sci 117: 233-242.

Bhattacharya G, Miller C, Kimberling WJ, Jablonski MM, Cosgrove D. 2002. Localization and expression of usherin: A novel basement membrane protein defective in 


\section{P.D. Yurchenco}

people with Usher's syndrome type IIa. Hear Res 163: $1-11$.

Bix G, Fu J, Gonzalez EM, Macro L, Barker A, Campbell S, Zutter MM, Santoro SA, Kim JK, Hook M, et al. 2004 Endorepellin causes endothelial cell disassembly of actin cytoskeleton and focal adhesions through $\alpha 2 \beta 1$ integrin. J Cell Biol 166: 97-109.

Bonaldo P, Russo V, Bucciotti F, Doliana R, Colombatti A 1990. Structural and functional features of the $\alpha 3$ chain indicate a bridging role for chicken collagen VI in connective tissues. Biochemistry 29: 1245-1254.

Borza CM, Pozzi A, Borza DB, Pedchenko V, Hellmark T, Hudson BG, Zent R. 2006. Integrin $\alpha 3 \beta 1$, a novel receptor for $\alpha 3$ (IV) noncollagenous domain and a transdominant Inhibitor for integrin $\alpha \mathrm{v} \beta 3$. J Biol Chem 281: 20932-20939.

Bose K, Nischt R, Page A, Bader BL, Paulsson M, Smyth N. 2006. Loss of nidogen-1 and -2 results in syndactyly and changes in limb development. J Biol Chem 281: 1157311581.

Bowman W. 1840. On the minute structure and movements of voluntary muscle. Philos Trans R Soc Lond Biol Sci 130: 457-494.

Bozzi M, Morlacchi S, Bigotti MG, Sciandra F, Brancaccio A. 2009. Functional diversity of dystroglycan. Matrix Biol 28: $179-187$.

Brandenberger R, Schmidt A, Linton J, Wang D, Backus C, Denda S, Muller U, Reichardt LF. 2001. Identification and characterization of a novel extracellular matrix protein nephronectin that is associated with integrin $\alpha 8 \beta 1$ in the embryonic kidney. J Cell Biol 154: 447-458.

Breedveld G, de Coo IF, Lequin MH, Arts WF, Heutink P, Gould DB, John SW, Oostra B, Mancini GM. 2006. Novel mutations in three families confirm a major role of COL4A1 in hereditary porencephaly. J Med Genet 43: 490-495.

Campbell AG, Fessler LI, Salo T, Fessler JH. 1987. Papilin: A Drosophila proteoglycan-like sulfated glycoprotein from basement membranes. J Biol Chem 262: 17605-17612.

Carter WG, Ryan MC, Gahr PJ. 1991. Epiligrin, a new cell adhesion ligand for integrin $\alpha 3 \beta 1$ in epithelial basement membranes. Cell 65: 599-610.

Caulfield JP, Farquhar MG. 1974. The permeability of glomerular capillaries to graded dextrans. Identification of the basement membrane as the primary filtration barrier. J Cell Biol 63: 883-903.

Chan FL, Inoue S. 1994. Lamina lucida of basement membrane: An artifact. Microsc Res Tech 28: 48-59.

Chan FL, Inoue S, Leblond CP. 1993. The basement membranes of cryofixed or aldehyde-fixed, freeze-substituted tissues are composed of a lamina densa and do not contain a lamina lucida. Cell Tissue Res 273: 41-52.

Cheng YS, Champliaud MF, Burgeson RE, Marinkovich MP, Yurchenco PD. 1997. Self-assembly of laminin isoforms. J Biol Chem 272: 31525-31532.

Cirulli V, Yebra M. 2007. Netrins: beyond the brain. Nat Rev Mol Cell Biol 8: 296-306.

Cohn RD, Henry MD, Michele DE, Barresi R, Saito F, Moore SA, Flanagan JD, Skwarchuk MW, Robbins ME, Mendell JR, et al. 2002. Disruption of DAG1 in differentiated skeletal muscle reveals a role for dystroglycan in muscle regeneration. Cell 110: 639-648.

Colognato H, Yurchenco PD. 1999. The laminin $\alpha 2$ expressed by dystrophic dy(2J) mice is defective in its ability to form polymers. Curr Biol 9: 1327-1330.

Colognato H, MacCarrick M, O'Rear JJ, Yurchenco PD. 1997. The laminin $\alpha 2$-chain short arm mediates cell adhesion through both the $\alpha 1 \beta 1$ and $\alpha 2 \beta 1$ integrins. J Biol Chem 272: 29330-29336.

Colognato H, Winkelmann DA, Yurchenco PD. 1999. Laminin polymerization induces a receptor-cytoskeleton network. J Cell Biol 145: 619-631.

Colognato-Pyke H, O'Rear JJ, Yamada Y, Carbonetto S, Cheng YS, Yurchenco PD. 1995. Mapping of networkforming, heparin-binding, and $\alpha 1 \beta 1$ integrin-recognition sites within the $\alpha$-chain short arm of laminin- 1 . J Biol Chem 270: 9398-9406.

Costell M, Gustafsson E, Aszodi A, Morgelin M, Bloch W, Hunziker E, Addicks K, Timpl R, Fässler R. 1999. Perlecan maintains the integrity of cartilage and some basement membranes. J Cell Biol 147: 1109-1122.

Deen WM. 2004. What determines glomerular capillary permeability?. J Clin Invest 114: 1412-1414.

Denzer AJ, Schulthess T, Fauser C, Schumacher B, Kammerer RA, Engel J, Ruegg MA. 1998. Electron microscopic structure of agrin and mapping of its binding site in laminin-1. Embo J 17: 335-343.

Di Persio CM, Hodivala-Dilke KM, Jaenisch R, Kreidberg JA, Hynes RO. 1997. $\alpha$ a3 $\beta 1$ integrin is required for normal development of the epidermal basement membrane. J Cell Biol 137: 729-742.

Domogatskaya A, Rodin S, Boutaud A, Tryggvason K. 2008. Laminin-511 but not $-332,-111$, or -411 enables mouse embryonic stem cell self-renewal in vitro. Stem Cells 26: 2800-2809.

Edwards MM, Mammadova-Bach E, Alpy F, Klein A, Hicks WL, Roux M, Simon-Assmann P, Smith RS, Orend G, Wu $\mathrm{J}$, et al. 2010. Mutations in Lamal disrupt retinal vascular development and inner limiting membrane formation. J Biol Chem 285: 7697-7711.

Engler AJ, Griffin MA, Sen S, Bonnemann CG, Sweeney HL, Discher DE. 2004. Myotubes differentiate optimally on substrates with tissue-like stiffness: Pathological implications for soft or stiff microenvironments. J Cell Biol 166: 877-887.

Ervasti JM, Campbell KP. 1993. A role for the dystrophinglycoprotein complex as a transmembrane linker among laminin and actin. J Cell Biol 122: 809-823.

Feltri ML, Graus Porta D, Previtali SC, Nodari A, Migliavacca B, Cassetti A, Littlewood-Evans A, Reichardt LF Messing A, Quattrini A, et al. 2002. Conditional disruption of $\beta 1$ integrin in Schwann cells impedes interactions with axons. J Cell Biol 156: 199-209.

Folkman J. 2004. Endogenous angiogenesis inhibitors. APMIS 112: 496-507.

Folkman J. 2006. Antiangiogenesis in cancer therapy-endostatin and its mechanisms of action. Exp Cell Res 312: 594-607.

Fox JW, Mayer U, Nischt R, Aumailley M, Reinhardt D, Wiedemann H, Mann K, Timpl R, Krieg T, Engel J, et al. 1991. Recombinant nidogen consists of three globular domains 
and mediates binding of laminin to collagen type IV EMBO J 10: 3137-3146.

Friedrich MV, Gohring W, Morgelin M, Brancaccio A, David G, Timpl R. 1999. Structural basis of glycosaminoglycan modification and of heterotypic interactions of perlecan domain V. J Mol Biol 294: 259-270.

Furthmayr H, Wiedemann H, Timpl R, Odermatt E, Engel J. 1983. Electron-microscopical approach to a structural model of intima collagen. Biochem J 211: 303-311.

Garbe JH, Gohring W, Mann K, Timpl R, Sasaki T. 2002. Complete sequence, recombinant analysis and binding to laminins and sulphated ligands of the N-terminal domains of laminin $[\alpha] 3 \mathrm{~B}$ and $[\alpha] 5$ chains. Biochem $J$ 362: $213-221$.

Gawlik KI, Akerlund M, Carmignac V, Elamaa H, Durbeej M. 2010. Distinct roles for laminin globular domains in laminin $\alpha 1$ chain mediated rescue of murine laminin $\alpha 2$ chain deficiency. PLoS ONE 5: e11549.

Gawlik KI, Li JY, Petersen A, Durbeej M. 2006. Laminin $\alpha 1$ chain improves laminin $\alpha 2$ chain deficient peripheral neuropathy. Hum Mol Genet 15: 2690-2700.

Georges-Labouesse E, Mark M, Messaddeq N, Gansmuller A. 1998. Essential role of $\alpha 6$ integrins in cortical and retinal lamination. Curr Biol 8: 983-986.

Georges-Labouesse E, Messaddeq N, Yehia G, Cadalbert L, Dierich A, Le Meur M. 1996. Absence of integrin $\alpha 6$ leads to epidermolysis bullosa and neonatal death in mice. $\mathrm{Nat}$ Genet 13: 370-373.

Gersdorff N, Kohfeldt E, Sasaki T, Timpl R, Miosge N. 2005. Laminin $\gamma 3$ chain binds to nidogen and is located in murine basement membranes. I Biol Chem 280: 22146-22153.

Gesemann M, Brancaccio A, Schumacher B, Ruegg MA. 1998. Agrin is a high-affinity binding protein of dystroglycan in non-muscle tissue. J Biol Chem 273: 600-605.

Giannelli G, Falk-Marzillier J, Schiraldi O, Stetler-Stevenson WG, Quaranta V. 1997. Induction of cell migration by matrix metalloprotease-2 cleavage of laminin-5. Science 277: $225-228$.

Gohring W, Sasaki T, Heldin CH, Timpl R. 1998. Mapping of the binding of platelet-derived growth factor to distinct domains of the basement membrane proteins BM-40 and perlecan and distinction from the BM-40 collagen-binding epitope. Eur J Biochem 255: 60-66.

Goldberg S, Adair-Kirk TL, Senior RM, Miner JH. 2010. Maintenance of glomerular filtration barrier integrity requires laminin $\alpha 5$. J Am Soc Nephrol 21: 579-586.

Goldfinger LE, Stack MS, Jones JC, Todorov IT, Scheyhing KI, Grzesiak JJ, Cruz-Aranda G, Stubban CB, Mullen Y, Halberstadt CR, et al. 1998. Processing of laminin-5 and its functional consequences: nrole of plasmin and tissue-type plasminogen activator Expansion of functional adult porcine islet cells in vitro using purified laminin 5: Coating of titanium alloy with soluble laminin-5 promotes cell attachment and hemidesmosome assembly in gingival epithelial cells: potential application to dental implants. J Cell Biol 141: 255-265.

Gould DB, Marchant JK, Savinova OV, Smith RS, John SW. 2007. Col4al mutation causes endoplasmic reticulum stress and genetically modifiable ocular dysgenesis. Hum Mol Genet 16: 798-807.
Gould DB, Phalan FC, Breedveld GJ, van Mil SE, Smith RS, Schimenti JC, Aguglia U, van der Knaap MS, Heutink P, John SW. 2005. Mutations in Col4al cause perinatal cerebral hemorrhage and porencephaly. Science 308: $1167-$ 1171.

Gould DB, Phalan FC, van Mil SE, Sundberg JP, Vahedi K, Massin P, Bousser MG, Heutink P, Miner JH, TournierLasserve E, et al. 2006. Role of COL4A1 in small-vessel disease and hemorrhagic stroke. N Engl J Med 354: 1489-1496.

Graus-Porta D, Blaess S, Senften M, Littlewood-Evans A, Damsky C, Huang Z, Orban P, Klein R, Schittny JC, Muller U. 2001. $\beta$-class integrins regulate the development of laminae and folia in the cerebral and cerebellar cortex. Neuron 31: 367-379.

Groggel GC, Hovingh P, Border WA, Linker A. 1987. Changes in glomerular heparan sulfate in puromycin aminonucleoside nephrosis. Am J Pathol 128: 521-527.

Groggel GC, Stevenson J, Hovingh P, Linker A, Border WA. 1988. Changes in heparan sulfate correlate with increased glomerular permeability. Kidney Int 33: 517-523.

Gunwar S, Ballester F, Noelken ME, Sado Y, Ninomiya Y, Hudson BG. 1998. Glomerular basement membrane. Identification of a novel disulfide-cross- linked network of $\alpha 3, \alpha 4$, and $\alpha 5$ chains of type IV collagen and its implications for the pathogenesis of Alport syndrome. J Biol Chem 273: 8767-8775.

Halfter W, Dong S, Yip YP, Willem M, Mayer U. 2002. A critical function of the pial basement membrane in cortical histogenesis. J Neurosci 22: 6029-6040.

Hamma-Kourbali Y, Vassy R, Starzec A, Le Meuth-Metzinger V, Oudar O, Bagheri-Yarmand R, Perret G, Crepin M. 2001. Vascular endothelial growth factor 165 (VEGF(165)) activities are inhibited by carboxymethyl benzylamide dextran that competes for heparin binding to $\operatorname{VEGF}(165)$ and VEGF(165).KDR Complexes. J Biol Chem 276: 39748-39754.

Han R, Kanagawa M, Yoshida-Moriguchi T, Rader EP, Ng RA, Michele DE, Muirhead DE, Kunz S, Moore SA, Iannaccone ST, et al. 2009. Basal lamina strengthens cell membrane integrity via the laminin G domain-binding motif of $\alpha$-dystroglycan. Proc Natl Acad Sci 106: 1257312579.

Harmer NJ, Robinson CJ, Adam LE, Ilag LL, Robinson CV, Gallagher JT, Blundell TL. 2006. Multimers of the fibroblast growth factor (FGF)-FGF receptor-saccharide complex are formed on long oligomers of heparin. Biochem $J$ 393: $741-748$.

Harrison D, Hussain SA, Combs AC, Ervasti JM, Yurchenco PD, Hohenester E. 2007. Crystal structure and cell surface anchorage sites of laminin $\alpha$ 1LG 4-5. J Biol Chem 282: 11573-11581.

Harvey SJ, Jarad G, Cunningham J, Rops AL, van der Vlag J, Berden JH, Moeller MJ, Holzman LB, Burgess RW, Miner JH. 2007. Disruption of glomerular basement membrane charge through podocyte-specific mutation of agrin does not alter glomerular permselectivity. Am J Pathol 171: $139-152$.

Haubst N, Georges-Labouesse E, De Arcangelis A, Mayer U, Gotz M. 2006. Basement membrane attachment is dispensable for radial glial cell fate and for proliferation, 


\section{P.D. Yurchenco}

but affects positioning of neuronal subtypes. Development 133: 3245-3254

He X, Liu J, Qi Y, Brakebusch C, Chrostek-Grashoff A, Edgar D, Yurchenco PD, Corbett SA, Lowry SF, Graham AM, et al. 2010. Rac1 is essential for basement membrane-dependent epiblast survival. Mol Cell Biol 30: 3569-3581.

Henry MD, Campbell KP. 1998. A role for dystroglycan in basement membrane assembly. Cell 95: 859-870.

Higuchi Y, Shiraki N, Yamane K, Qin Z, Mochitate K, Araki K, Senokuchi T, Yamagata K, Hara M, Kume K, et al. 2010. Synthesized basement membranes direct the differentiation of mouse embryonic stem cells into pancreatic lineages. J Cell Sci 123: 2733-2742.

Hopf M, Gohring W, Kohfeldt E, Yamada Y, Timpl R. 1999. Recombinant domain IV of perlecan binds to nidogens, laminin-nidogen complex, fibronectin, fibulin-2 and heparin. Eur J Biochem 259: 917-925.

Hopf M, Gohring W, Mann K, Timpl R. 2001. Mapping of binding sites for nidogens, fibulin-2, fibronectin and heparin to different ig modules of perlecan. J Mol Biol 311: 529-541.

Huang JT, Lee V. 2005. Identification and characterization of a novel human nephronectin gene in silico. Int J Mol Med 15: 719-724.

Huang CC, Hall DH, Hedgecock EM, Kao G, Karantza V, Vogel BE, Hutter H, Chisholm AD, Yurchenco PD, Wadsworth WG. 2003. Laminin $\alpha$ subunits and their role in C. elegans development. Development 130: 3343-3358.

Huber AR, Weiss SJ. 1989. Disruption of the subendothelial basement membrane during neutrophil diapedesis in an in vitro construct of a blood vessel wall. J Clin Invest 83: $1122-1136$.

Hudson BG, Tryggvason K, Sundaramoorthy M, Neilson EG. 2003. Alport's syndrome, Goodpasture's syndrome, and type IV collagen. N Engl J Med 348: 2543-2556.

Huebsch N, Arany PR, Mao AS, Shvartsman D, Ali OA, Bencherif SA, Rivera-Feliciano J, Mooney DJ. 2010. Harnessing traction-mediated manipulation of the cell/ matrix interface to control stem-cell fate. Nat Mater 9: $518-526$.

Ido H, Ito S, Taniguchi Y, Hayashi M, Sato-Nishiuchi R, Sanzen N, Hayashi Y, Futaki S, Sekiguchi K. 2008. Laminin isoforms containing the $\gamma 3$ chain are unable to bind to integrins due to the absence of the glutamic acid residue conserved in the C-terminal regions of the $\gamma 1$ and $\gamma 2$ chains. J Biol Chem 283: 28149-28157.

Ido H, Nakamura A, Kobayashi R, Ito S, Li S, Futaki S, Sekiguchi K. 2007. The requirement of the glutamic acid residue at the third position from the carboxyl termini of the laminin $\gamma$ chains in integrin binding by laminins. J Biol Chem 282: 11144-11154.

Inoue S, Leblond CP, Laurie GW. 1983. Ultrastructure of Reichert's membrane, a multilayered basement membrane in the parietal wall of the rat yolk sac. J Cell Biol 97: $1524-1537$.

Iozzo RV, Zoeller JJ, Nystrom A. 2009. Basement membrane proteoglycans: modulators Par Excellence of cancer growth and angiogenesis. Mol Cells 27: 503-513.

Jarad G, Cunningham J, Shaw AS, Miner JH. 2006. Proteinuria precedes podocyte abnormalities inLamb2 mice, implicating the glomerular basement membrane as an albumin barrier. J Clin Invest 116: 2272-2279.

Jessen KR, Mirsky R. 2005. The origin and development of glial cells in peripheral nerves. Nat Rev Neurosci 6: 671-682.

Kalb E, Engel J. 1991. Binding and calcium-induced aggregation of laminin onto lipid bilayers. J Biol Chem 266: 19047-19052.

Kalkhof S, Haehn S, Ihling C, Paulsson M, Smyth N, Sinz A. 2008. Determination of disulfide bond patterns in laminin betal chain N-terminal domains by nano-highperformance liquid chromatography/matrix-assisted laser desorption/ionization time-of-flight/time-of-flight mass spectrometry. Rapid Commun Mass Spectrom 22: 1933-1940.

Kammerer RA, Schulthess T, Landwehr R, Schumacher B, Lustig A, Yurchenco PD, Ruegg MA, Engel J, Denzer AJ. 1999. Interaction of agrin with laminin requires a coiled-coil conformation of the agrin-binding site within the laminin $\gamma 1$ chain. Embo J 18: 6762-6770.

Katsumi A, Naoe T, Matsushita T, Kaibuchi K, Schwartz MA. 2005. Integrin activation and matrix binding mediate cellular responses to mechanical stretch. J Biol Chem 280: 16546-16549.

Katsumi A, Orr AW, Tzima E, Schwartz MA. 2004. Integrins in mechanotransduction. J Biol Chem 279: 1200112004.

Kennedy TE, Serafini T, de la Torre JR, Tessier-Lavigne M. 1994. Netrins are diffusible chemotropic factors for commissural axons in the embryonic spinal cord. Cell 78: 425-435.

Kestila M, Lenkkeri U, Mannikko M, Lamerdin J, McCready P, Putaala H, Ruotsalainen V, Morita T, Nissinen M, Herva R, et al. 1998. Positionally cloned gene for a novel glomerular protein-nephrin-is mutated in congenital nephrotic syndrome. Mol Cell 1: 575-582.

Kikkawa Y, Miner JH. 2006. Molecular dissection of laminin $\alpha 5$ in vivo reveals separable domain-specific roles in embryonic development and kidney function. Dev Biol. 296: $265-277$.

Kikkawa Y, Moulson CL, Virtanen I, Miner JH. 2002. Identification of the binding site for the Lutheran blood group glycoprotein on laminin $\alpha 5$ through expression of chimeric laminin chains in vivo. J Biol Chem 277: $44864-$ 44869.

Koshikawa N, Minegishi T, Sharabi A, Quaranta V, Seiki M. 2005. Membrane-type matrix metalloproteinase-1 (MT1-MMP) is a processing enzyme for human laminin $\gamma 2$ chain. J Biol Chem 280: 88-93.

Kosodo Y, Huttner WB. 2009. Basal process and cell divisions of neural progenitors in the developing brain. Dev Growth Differ 51: 251-261.

Kramerova IA, Kawaguchi N, Fessler LI, Nelson RE, Chen Y, Kramerov AA, Kusche-Gullberg M, Kramer JM, Ackley BD, Sieron AL, et al. 2000. Papilin in development; a pericellular protein with a homology to the ADAMTS metalloproteinases. Development 127: 5475-5485.

Kreidberg JA, Donovan MJ, Goldstein SL, Rennke H, Shepherd K, Jones RC, Jaenisch R. 1996. $\alpha$ a3 $\beta 1$ integrin has a crucial role in kidney and lung organogenesis. Development 122: 3537-3547. 
Kuo HJ, Maslen CL, Keene DR, Glanville RW. 1997. Type VI collagen anchors endothelial basement membranes by interacting with type IV collagen. J Biol Chem 272: 26522-26529.

Lampe AK, Bushby KM. 2005. Collagen VI related muscle disorders. J Med Genet 42: 673-685.

Lefeber DJ, Schonberger J, Morava E, Guillard M, Huyben KM, Verrijp K, Grafakou O, Evangeliou A, Preijers FW, Manta P, et al. 2009. Deficiency of Dol-P-Man synthase subunit DPM3 bridges the congenital disorders of glycosylation with the dystroglycanopathies. Am J Hum Genet 85: 76-86.

Li Q, Loeb JA. 2001. Neuregulin-heparan-sulfate proteoglycan interactions produce sustained erbB receptor activation required for the induction of acetylcholine receptors in muscle. J Biol Chem 276: 38068-38075.

Li S, Bordoy R, Stanchi F, Moser M, Braun A, Kudlacek O, Wewer UM, Yurchenco PD, Fässler R. 2005a. PINCH1 regulates cell-matrix and cell-cell adhesions, cell polarity and cell survival during the peri-implantation stage. J Cell Sci 118: 2913-2921.

Li S, Edgar D, Fässler R, Wadsworth W, Yurchenco PD. 2003b. The role of laminin in embryonic cell polarization and tissue organization. Dev Cell 4: 613-624.

Li S, Harrison D, Carbonetto S, Fässler R, Smyth N, Edgar D, Yurchenco PD. 2002. Matrix assembly, regulation, and survival functions of laminin and its receptors in embryonic stem cell differentiation. J Cell Biol 157: 1279-1290.

Li S, Liquari P, McKee KK, Harrison D, Patel R, Lee S, Yurchenco PD. 2005b. Laminin-sulfatide binding initiates basement membrane assembly and enables receptor signaling in Schwann cells and fibroblasts. J Cell Biol 169: 179-189.

Li J, Tzu J, Chen Y, Zhang YP, Nguyen NT, Gao J, Bradley M, Keene DR, Oro AE, Miner JH, et al. 2003a. Laminin-10 is crucial for hair morphogenesis. Embo J 22: 2400-2410.

Lin S, Maj M, Bezakova G, Magyar JP, Brenner HR, Ruegg MA. 2008. Muscle-wide secretion of a miniaturized form of neural agrin rescues focal neuromuscular innervation in agrin mutant mice. Proc Natl Acad Sci 105: 11406-11411.

Linton JM, Martin GR, Reichardt LF. 2007. The ECM protein nephronectin promotes kidney development via integrin $\alpha 8 \beta 1$-mediated stimulation of Gdnf expression. Development 134: 2501-2509.

Litjens SH, de Pereda JM, Sonnenberg A. 2006. Current insights into the formation and breakdown of hemidesmosomes. Trends Cell Biol 16: 376-383.

Macdonald PR, Lustig A, Steinmetz MO, Kammerer RA. 2010. Laminin chain assembly is regulated by specific coiled-coil interactions. J Struct Biol 170: 398-405.

Maeda Y, Kinoshita T. 2008. Dolichol-phosphate mannose synthase: structure, function and regulation. Biochim Biophys Acta 1780: 861-868.

Maeshima Y, Colorado PC, Kalluri R. 2000. Two RGD-independent $\alpha v \beta 3$ integrin binding sites on tumstatin regulate distinct anti-tumor properties. J Biol Chem 275: 23745-23750.

Marinkovich MP, Lunstrum GP, Burgeson RE. 1992a. The anchoring filament protein kalinin is synthesized and secreted as a high molecular weight precursor. $J$ Biol Chem 267: 17900-17906.

Marinkovich MP, Lunstrum GP, Keene DR, Burgeson RE. 1992b. The dermal-epidermal junction of human skin contains a novel laminin variant. J Cell Biol 119: 695-703.

Marneros AG, Olsen BR. 2005. Physiological role of collagen XVIII and endostatin. Faseb J 19: 716-728.

Matejas V, Hinkes B, Alkandari F, Al-Gazali L, Annexstad E, Aytac MB, Barrow M, Blahova K, Bockenhauer D, Cheong HI, et al. 2010. Mutations in the human laminin $\beta 2$ (LAMB2) gene and the associated phenotypic spectruma. Hum Mutat 31: 992-1002.

Mayer U, Timpl R. 1994. Nidogen: Aversatile binding protein of basement membranes. In Extracellular matrix assembly and structure (ed. PD Yurchenco, DE Birk, RP Mechan), pp. 389-416. Academic Press, New York.

Mayer U, Saher G, Fässler R, Bornemann A, Echtermeyer F von der Mark H, Miosge N, Pöschl E, von der Mark K. 1997. Absence of integrin $\alpha 7$ causes a novel form of muscular dystrophy. Nat Genet 17: 318-323.

McKee KK, Capizzi S, Yurchenco PD. 2009. Scaffoldforming and adhesive contributions of synthetic laminin-binding proteins to basement membrane assembly. J Biol Chem 284: 8984-8994.

McKee KK, Harrison D, Capizzi S, Yurchenco PD. 2007. Role of laminin terminal globular domains in basement membrane assembly. J Biol Chem 282: 21437-21447.

Meier T, Hauser DM, Chiquet M, Landmann L, Ruegg MA, Brenner HR. 1997. Neural agrin induces ectopic postsynaptic specializations in innervated muscle fibers. J Neurosci 17: 6534-6544.

Miner JH, Li C. 2000. Defective glomerulogenesis in the absence of laminin $\alpha 5$ demonstrates a developmental role for the kidney glomerular basement membrane. Dev Biol 217: 278-289.

Miner JH, Sanes JR. 1994. Collagen IV $\alpha 3, \alpha 4$, and $\alpha 5$ chains in rodent basal laminae: sequence, distribution, association with laminins, and developmental switches. J Cell Biol 127: 879-891.

Miner JH, Yurchenco PD. 2004. Laminin functions in tissue morphogenesis. Annu Rev Cell Dev Biol 20: 255-284.

Miner JH, Cunningham J, Sanes JR. 1998. Roles for laminin in embryogenesis: Exencephaly, syndactyly, and placentopathy in mice lacking the laminin $\alpha 5$ chain. J Cell Biol 143: $1713-1723$.

Miner JH, Li C, Mudd JL, Go G, Sutherland AE. 2004. Compositional and structural requirements for laminin and basement membranes during mouse embryo implantation and gastrulation. Development 131: 2247-2256.

Miner JH, Patton BL, Lentz SI, Gilbert DJ, Snider WD, Jenkins NA, Copeland NG, Sanes JR. 1997. The laminin achains: Expression, developmental transitions, and chromosomal locations of $\alpha 1-5$, identification of heterotrimeric laminins $8-11$, and cloning of a novel $\alpha 3$ isoform. J Cell Biol 137: 685-701.

Miosge N. 2001. The ultrastructural composition of basement membranes in vivo. Histol Histopathol 16: 12391248. 
P.D. Yurchenco

Mitsuhashi Y, Hashimoto I. 2003. Genetic abnormalities and clinical classification of epidermolysis bullosa. Arch Dermatol Res 295: 29-33.

Miyagoe Y, Hanaoka K, Nonaka I, Hayasaka M, Nabeshima Y, Arahata K, Nabeshima Y, Takeda S. 1997. Laminin $\alpha 2$ chain-null mutant mice by targeted disruption of the Lama2 gene: a new model of merosin (laminin 2)-deficient congenital muscular dystrophy. FEBS Lett 415: 33-39.

Miyamoto S, Teramoto H, Gutkind JS, Yamada KM. 1996. Integrins can collaborate with growth factors for phosphorylation of receptor tyrosine kinases and MAP kinase activation: Roles of integrin aggregation and occupancy of receptors. J Cell Biol 135: 1633-1642.

Moll J, Barzaghi P, Lin S, Bezakova G, Lochmuller H, Engvall E, Muller U, Ruegg MA. 2001. An agrin minigene rescues dystrophic symptoms in a mouse model for congenital muscular dystrophy. Nature 413: 302-307.

Mongiat M, Otto J, Oldershaw R, Ferrer F, Sato JD, Iozzo RV. 2001. Fibroblast growth factor-binding protein is a novel partner for perlecan protein core. J Biol Chem 276: 10263-10271.

Montanez E, Ussar S, Schifferer M, Bosl M, Zent R, Moser M, Fässler R. 2008. Kindlin-2 controls bidirectional signaling of integrins. Genes Dev 22: 1325-1330.

Moore SA, Saito F, Chen J, Michele DE, Henry MD, Messing A, Cohn RD, Ross-Barta SE, Westra S, Williamson RA, et al. 2002. Deletion of brain dystroglycan recapitulates aspects of congenital muscular dystrophy. Nature 418: $422-425$.

Moulson CL, Li C, Miner JH. 2001. Localization of Lutheran, a novel laminin receptor, in normal, knockout, and transgenic mice suggests an interaction with laminin $\alpha 5$ in vivo. Dev Dyn 222: 101-114.

Murray P, Edgar D. 2000. Regulation of programmed cell death by basement membranes in embryonic development. J Cell Biol 150: 1215-1221.

Myers JC, Dion AS, Abraham V, Amenta PS. 1996. Type XV collagen exhibits a widespread distribution in human tissues but a distinct localization in basement membrane zones. Cell Tissue Res 286: 493-505.

Myers JC, Li D, Amenta PS, Clark CC, Nagaswami C, Weisel JW, Hadad S, Lee MT, Barnard N. 2003. Type XIX collagen purified from human umbilical cord is characterized by multiple sharp kinks delineating collagenous subdomains and by intermolecular aggregates via globular, disulfide-linked, and heparin-binding amino termini. J Biol Chem 278: 32047-32057.

Myers JC, Li D, Bageris A, Abraham V, Dion AS, Amenta PS. 1997. Biochemical and immunohistochemical characterization of human type XIX defines a novel class of basement membrane zone collagens. Am J Pathol 151: 17291740.

Nielsen PK, Yamada Y. 2001. Identification of cell-binding sites on the Laminin $\alpha 5$ N-terminal domain by sitedirected mutagenesis. J Biol Chem 276: 10906-10912.

Niewmierzycka A, Mills J, St-Arnaud R, Dedhar S, Reichardt LF. 2005. Integrin-linked kinase deletion from mouse cortex results in cortical lamination defects resembling cobblestone lissencephaly. J Neurosci 25: 7022-7031.

Nikolova G, Jabs N, Konstantinova I, Domogatskaya A, Tryggvason K, Sorokin L, Fässler R, Gu G, Gerber HP,
Ferrara N, et al. 2006. The vascular basement membrane: A niche for insulin gene expression and $\beta$ cell proliferation. Dev Cell 10: 397-405.

Nishiuchi R, Takagi J, Hayashi M, Ido H, Yagi Y, Sanzen N, Tsuji T, Yamada M, Sekiguchi K. 2006. Ligand-binding specificities of laminin-binding integrins: A comprehensive survey of laminin-integrin interactions using recombinant $\alpha 3 \beta 1, \alpha 6 \beta 1, \alpha 7 \beta 1$ and $\alpha 6 \beta 4$ integrins. Matrix Biol 25: 189-197.

Noakes PG, Gautam M, Mudd J, Sanes JR, Merlie JP. 1995a. Aberrant differentiation of neuromuscular junctions in mice lacking s- laminin/laminin $\beta 2$. Nature 374: 258-262.

Noakes PG, Miner JH, Gautam M, Cunningham JM, Sanes JR, Merlie JP. 1995b. The renal glomerulus of mice lacking s-laminin/laminin $\beta 2$ : Nephrosis despite molecular compensation by laminin $\beta 1$. Nat Genet 10: 400-406.

Nodari A, Previtali SC, Dati G, Occhi S, Court FA, Colombelli C, Zambroni D, Dina G, Del Carro U, Campbell KP, et al. 2008. $\alpha 6 \beta 4$ integrin and dystroglycan cooperate to stabilize the myelin sheath. J Neurosci 28: 6714-6719.

Nyberg P, Xie L, Kalluri R. 2005. Endogenous inhibitors of angiogenesis. Cancer Res 65: 3967-3979.

Odenthal U, Haehn S, Tunggal P, Merkl B, Schomburg D, Frie C, Paulsson M, Smyth N. 2004. Molecular analysis of laminin N-terminal domains mediating self-interactions. J Biol Chem 279: 44505-44512.

Oppizzi ML, Akhavan A, Singh M, Fata JE, Muschler JL. 2008. Nuclear translocation of $\beta$-dystroglycan reveals a distinctive trafficking pattern of autoproteolyzed mucins. Traffic 9: 2063-2072.

Parsons MJ, Campos I, Hirst EM, Stemple DL. 2002. Removal of dystroglycan causes severe muscular dystrophy in zebrafish embryos. Development 129: 3505-3512.

Patton BL, Wang B, Tarumi YS, Seburn KL, Burgess RW. 2008. A single point mutation in the LN domain of LAMA2 causes muscular dystrophy and peripheral amyelination. J Cell Sci.

Paulsson M, Yurchenco PD, Ruben GC, Engel J, Timpl R. 1987. Structure of low density heparan sulfate proteoglycan isolated from a mouse tumor basement membrane. J Mol Biol 197: 297-313.

Pereira JA, Benninger Y, Baumann R, Goncalves AF, Ozcelik M, Thurnherr T, Tricaud N, Meijer D, Fässler R, Suter U, et al. 2009. Integrin-linked kinase is required for radial sorting of axons and Schwann cell remyelination in the peripheral nervous system. J Cell Biol 185: 147-161.

Petitclerc E, Boutaud A, Prestayko A, Xu J, Sado Y, Ninomiya Y, Sarras MP Jr, Hudson BG, Brooks PC. 2000. New functions for non-collagenous domains of human collagen type IV. Novel integrin ligands inhibiting angiogenesis and tumor growth in vivo. J Biol Chem 275: 8051-8061.

Plotnikov AN, Schlessinger J, Hubbard SR, Mohammadi M. 1999. Structural basis for FGF receptor dimerization and activation. Cell 98: 641-650.

Pöschl E, Fox JW, Block D, Mayer U, Timpl R. 1994. Two non-contiguous regions contribute to nidogen binding to a single EGF-like motif of the laminin gamma 1 chain. EMBO J 13: 3741-3747.

Pöschl E, Mayer U, Stetefeld J, Baumgartner R, Holak TA, Huber R, Timpl R. 1996. Site-directed mutagenesis and 
structural interpretation of the nidogen binding site of the laminin gammal chain. Embo J 15: 5154-5159.

Pöschl E, Schlotzer-Schrehardt U, Brachvogel B, Saito K, Ninomiya Y, Mayer U. 2004. Collagen IV is essential for basement membrane stability but dispensable for initiation of its assembly during early development. Development 131: 1619-1628.

Reiners J, Nagel-Wolfrum K, Jurgens K, Marker T, Wolfrum U. 2006. Molecular basis of human Usher syndrome: Deciphering the meshes of the Usher protein network provides insights into the pathomechanisms of the Usher disease. Exp Eye Res 83: 97-119.

Rider CC. 2006. Heparin/heparan sulphate binding in the TGF- $\beta$ cytokine superfamily. Biochem Soc Trans 34: $458-460$.

Ries A, Gohring W, Fox JW, Timpl R, Sasaki T. 2001 Recombinant domains of mouse nidogen- 1 and their binding to basement membrane proteins and monoclonal antibodies. Eur J Biochem 268: 5119-5128.

Rodin S, Domogatskaya A, Strom S, Hansson EM, Chien KR, Inzunza J, Hovatta O, Tryggvason K. 2010. Longterm self-renewal of human pluripotent stem cells on human recombinant laminin-511. Nat Biotechnol 28: 611-615.

Rousselle P, Keene DR, Ruggiero F, Champliaud MF, Rest M, Burgeson RE. 1997. Laminin 5 binds the NC-1 domain of type VII collagen. J Cell Biol 138: 719-728.

Rousselle P, Lunstrum GP, Keene DR, Burgeson RE. 1991. Kalinin: An epithelium-specific basement membrane adhesion molecule that is a component of anchoring filaments. J Cell Biol 114: 567-576.

Rowe RG, Weiss SJ. 2008. Breaching the basement membrane: Who, when and how? Trends Cell Biol 18: 560 574.

Ryan MC, Lee K, Miyashita Y, Carter WG. 1999. Targeted disruption of the LAMA3 gene in mice reveals abnormalities in survival and late stage differentiation of epithelial cells. J Cell Biol 145: 1309-1324.

Rybakova IN, Humston JL, Sonnemann KJ, Ervasti JM. 2006. Dystrophin and utrophin bind actin through distinct modes of contact. J Biol Chem 281: 9996-10001.

Saito F, Moore SA, Barresi R, Henry MD, Messing A, RossBarta SE, Cohn RD, Williamson RA, Sluka KA, Sherman DL, et al. 2003. Unique role of dystroglycan in peripheral nerve myelination, nodal structure, and sodium channel stabilization. Neuron 38: 747-758.

Sakai T, Li S, Docheva D, Grashoff C, Sakai K, Kostka G, Braun A, Pfeifer A, Yurchenco PD, Fässler R. 2003. Integrin-linked kinase (ILK) is required for polarizing the epiblast, cell adhesion, and controlling actin accumulation. Genes Dev 17: 926-940.

Sasaki T, Gohring W, Mann K, Brakebusch C, Yamada Y, Fässler R, Timpl R. 2001. Short arm region of laminin-5 $\gamma 2$ chain: Structure, mechanism of processing and binding to heparin and proteins. J Mol Biol 314: 751-763.

Sato Y, Uemura T, Morimitsu K, Sato-Nishiuchi R, Manabe R, Takagi J, Yamada M, Sekiguchi K. 2009. Molecular basis of the recognition of nephronectin by integrin alpha8beta1. J Biol Chem 284: 14524-14536.

Schenk S, Hintermann E, Bilban M, Koshikawa N, Hojilla C, Khokha R, Quaranta V. 2003. Binding to EGF receptor of a laminin-5 EGF-like fragment liberated during MMPdependent mammary gland involution. J Cell Biol 161: 197-209.

Schlessinger J, Plotnikov AN, Ibrahimi OA, Eliseenkova AV, Yeh BK, Yayon A, Linhardt RJ, Mohammadi M. 2000. Crystal structure of a ternary FGF-FGFR-heparin complex reveals a dual role for heparin in FGFR binding and dimerization. Mol Cell 6: 743-750.

Schneiders FI, Maertens B, Bose K, Li Y, Brunken WJ, Paulsson M, Smyth N, Koch M. 2007. Binding of netrin-4 to laminin short arms regulates basement membrane assembly. J Biol Chem 282: 23750-23758.

Sherwood DR, Butler JA, Kramer JM, Sternberg PW. 2005. FOS-1 promotes basement-membrane removal during anchor-cell invasion in C. elegans. Cell 121: 951-962.

Siebold B, Qian RA, Glanville RW, Hofmann H, Deutzmann R, Kuhn K. 1987. Construction of a model for the aggregation and cross-linking region (7S domain) of type IV collagen based upon an evaluation of the primary structure of the $\alpha 1$ and $\alpha 2$ chains in this region. Eur J Biochem 168: $569-575$.

Smirnov SP, McDearmon EL, Li S, Ervasti JM, Tryggvason K, Yurchenco PD. 2002. Contributions of the LG modules and furin processing to laminin-2 functions. J Biol Chem 277: 18928-18937.

Smyth N, Vatansever HS, Meyer M, Frie C, Paulsson M, Edgar D. 1998. The targeted deletion of the LAMC1 gene. Ann N Y Acad Sci 857: 283-286.

Smyth N, Vatansever HS, Murray P, Meyer M, Frie C, Paulsson M, Edgar D. 1999. Absence of basement membranes after targeting the LAMC1 gene results in embryonic lethality due to failure of endoderm differentiation. J Cell Biol 144: 151-160.

Sotgia F, Bonuccelli G, Bedford M, Brancaccio A, Mayer U, Wilson MT, Campos-Gonzalez R, Brooks JW, Sudol M, Lisanti MP. 2003. Localization of phospho- $\beta$-dystroglycan (pY892) to an intracellular vesicular compartment in cultured cells and skeletal muscle fibers in vivo. Biochemistry 42: 7110-7123.

Stanco A, Szekeres C, Patel N, Rao S, Campbell K, Kreidberg JA, Polleux F, Anton ES. 2009. Netrin-1- $\alpha 3 \beta 1$ integrin interactions regulate the migration of interneurons through the cortical marginal zone. Proc Natl Acad Sci 106: $7595-7600$.

Streuli CH, Bailey N, Bissell MJ. 1991. Control of mammary epithelial differentiation: basement membrane induces tissue-specific gene expression in the absence of cell-cell interaction and morphological polarity. J Cell Biol 115: 1383-1395.

Streuli CH, Schmidhauser C, Bailey N, Yurchenco P, Skubitz AP, Roskelley C, Bissell MJ. 1995. Laminin mediates tissue-specific gene expression in mammary epithelia. J Cell Biol 129: 591-603.

Sugawara K, Tsuruta D, Ishii M, Jones JC, Kobayashi H. 2008. Laminin-332 and -511 in skin. Exp Dermatol 17: 473-480.

Sunada Y, Bernier SM, Utani A, Yamada Y, Campbell KP. 1995a. Identification of a novel mutant transcript of laminin $\alpha 2$ chain gene responsible for muscular dystrophy and dysmyelination in dy2J mice. Hum Mol Genet 4: 1055-1061. 
P.D. Yurchenco

Sunada Y, Edgar TS, Lotz BP, Rust RS, Campbell KP. 1995b. Merosin-negative congenital muscular dystrophy associated with extensive brain abnormalities. Neurology 45: 2084-2089.

Sundaramoorthy M, Meiyappan M, Todd P, Hudson BG 2002. Crystal structure of NC1 domains: Structural basis for type IV collagen assembly in basement membranes. J Biol Chem 277: 31142-31153.

Takagi J. 2007. Structural basis for ligand recognition by integrins. Curr Opin Cell Biol 19: 557-564.

Takagi J, Yang Y, Liu JH, Wang JH, Springer TA. 2003. Complex among nidogen and laminin fragments reveals a paradigmatic $\beta$-propeller interface. Nature 424: $969-$ 974.

Talts JF, Andac Z, Gorhing W, Brancaccio A, Timpl R. 1999. Binding of the $G$ domains of laminin $\alpha 1$ and $\alpha 2$ chains and perlecan to heparin, sulfatides, $\alpha$-dystroglycan and several extracellular matrix proteins. Embo J 18: 863-870.

Talts JF, Sasaki T, Miosge N, Gohring W, Mann K, Mayne R, Timpl R. 2000. Structural and functional analysis of the recombinant $\mathrm{G}$ domain of the laminin $\{\alpha\} 4$ chain and its proteolytic processing in tissues. J Biol Chem 275: 35192-35199.

Taniguchi Y, Ido H, Sanzen N, Hayashi M, Sato-Nishiuchi R, Futaki S, Sekiguchi K. 2009. The C-terminal region of laminin beta chains modulates the integrin binding affinities of laminins. J Biol Chem 284: 7820-7831.

Than ME, Henrich S, Huber R, Ries A, Mann K, Kuhn K, Timpl R, Bourenkov GP, Bartunik HD, Bode W. 2002. The 1.9-A crystal structure of the noncollagenous (NC1) domain of human placenta collagen IV shows stabilization via a novel type of covalent Met-Lys cross-link. Proc Natl Acad Sci 99: 6607-6612.

Thyboll J, Kortesmaa J, Cao R, Soininen R, Wang L, Iivanainen A, Sorokin L, Risling M, Cao Y, Tryggvason K. 2002. Deletion of the laminin $\alpha 4$ chain leads to impaired microvessel maturation. Mol Cell Biol 22: 1194-1202.

Timpl R, Wiedemann H, van Delden V, Furthmayr H, Kuhn K. 1981. A network model for the organization of type IV collagen molecules in basement membranes. Eur J Biochem 120: 203-211.

Urbano JM, Torgler CN, Molnar C, Tepass U, Lopez-Varea A, Brown NH, de Celis JF, Martin-Bermudo MD. 2009. Drosophila laminins act as key regulators of basement membrane assembly and morphogenesis. Development 136: $4165-4176$.

von der mark K, Park J, Bauer S, Schmuki P. 2010. Nanoscale engineering of biomimetic surfaces: Cues from the extracellular matrix. Cell Tissue Res 339: 131-153.

Wallquist W, Plantman S, Thams S, Thyboll J, Kortesmaa J, Lannergren J, Domogatskaya A, Ogren SO, Risling M, Hammarberg H, et al. 2005. Impeded interaction among Schwann cells and axons in the absence of laminin alpha4. J Neurosci 25: 3692-3700.

Wartiovaara J, Ofverstedt LG, Khoshnoodi J, Zhang J, Makela E, Sandin S, Ruotsalainen V, Cheng RH, Jalanko H, Skoglund U, et al. 2004. Nephrin strands contribute to a porous slit diaphragm scaffold as revealed by electron tomography. J Clin Invest 114: 1475-1483.

Webster HD, Martin R, O'Connell MF. 1973. The relationships among interphase Schwann cells and axons before myelination: A quantitative electron microscopic study. Dev Biol 32: 401-416.

Weir ML, Oppizzi ML, Henry MD, Onishi A, Campbell KP, Bissell MJ, Muschler JL. 2006. Dystroglycan loss disrupts polarity and $\{\beta\}$-casein induction in mammary epithelial cells by perturbing laminin anchoring. J Cell Sci 119: 4047-4058.

Willem M, Miosge N, Halfter W, Smyth N, Jannetti I, Burghart E, Timpl R, Mayer U. 2002. Specific ablation of the nidogen-binding site in the laminin gammal chain interferes with kidney and lung development. Development 129: 2711-2722.

Williamson RA, Henry MD, Daniels KJ, Hrstka RF, Lee JC, Sunada Y, Ibraghimov-Beskrovnaya O, Campbell KP. 1997. Dystroglycan is essential for early embryonic development: Disruption of Reichert's membrane in Dag1null mice. Hum Mol Genet 6: 831-841.

Wizemann H, Garbe JH, Friedrich MV, Timpl R, Sasaki T, Hohenester E. 2003. Distinct requirements for heparin and $\alpha$-dystroglycan binding revealed by structure-based mutagenesis of the laminin $\alpha 2$ LG4-LG5 domain pair. J Mol Biol 332: 635-642.

Wu C, Ivars F, Anderson P, Hallmann R, Vestweber D, Nilsson P, Robenek H, Tryggvason K, Song J, Korpos E, et al. 2009. Endothelial basement membrane laminin $\alpha 5$ selectively inhibits T lymphocyte extravasation into the brain. Nat Med 15: 519-527.

Wu X, Li S, Chrostek-Grashoff A, Czuchra A, Meyer H, Yurchenco PD, Brakebusch C. 2007. Cdc42 is crucial for the establishment of epithelial polarity during early mammalian development. Dev Dyn 236: 2767-2778.

Wuhl E, Kogan J, Zurowska A, Matejas V, Vandevoorde RG, Aigner T, Wendler O, Lesniewska I, Bouvier R, Reis A, et al. 2007. Neurodevelopmental deficits in Pierson (microcoria-congenital nephrosis) syndrome. Am J Med Genet A 143: 311-319.

Xiong Y, Zhou Y, Jarrett HW. 2009. Dystrophin glycoprotein complex-associated G $\beta \gamma$ subunits activate phosphatidylinositol-3-kinase/Akt signaling in skeletal muscle in a laminin-dependent manner. J Cell Physiol 219: 402-414.

Yang D, Bierman J, Tarumi YS, Zhong YP, Rangwala R, Proctor TM, Miyagoe-Suzuki Y, Takeda S, Miner JH, Sherman LS, et al. 2005. Coordinate control of axon defasciculation and myelination by laminin-2 and -8. J Cell Biol 168: 655-666.

Yin Y, Sanes JR, Miner JH. 2000. Identification and expression of mouse netrin-4. Mech Dev 96: 115-119.

Yoshida-Moriguchi T, Yu L, Stalnaker SH, Davis S, Kunz S, Madson M, Oldstone MB, Schachter H, Wells L, Campbell KP. 2010. O-mannosyl phosphorylation of $\alpha$-dystroglycan is required for laminin binding. Science 327: 88-92.

Yu WM, Chen ZL, North AJ, Strickland S. 2009. Laminin is required for Schwann cell morphogenesis. J Cell Sci 122: 929-936.

Yu WM, Feltri ML, Wrabetz L, Strickland S, Chen ZL. 2005. Schwann cell-specific ablation of laminin gammal causes apoptosis and prevents proliferation. J Neurosci 25: 4463-4472.

Yurchenco PD, Cheng YS. 1993. Self-assembly and calciumbinding sites in laminin. A three-arm interaction model. J Biol Chem 268: 17286-17299. 
Yurchenco PD, Furthmayr H. 1984. Self-assembly of basement membrane collagen. Biochemistry 23: 1839-1850.

Yurchenco PD, Ruben GC. 1987. Basement membrane structure in situ: Evidence for lateral associations in the type IV collagen network. J Cell Biol 105: 2559-2568.

Yurchenco PD, Wadsworth WG. 2004. Assembly and tissue functions of early embryonic laminins and netrins. Curr Opin Cell Biol 16: 572-579.

Yurchenco PD, Cheng YS, Colognato H. 1992. Laminin forms an independent network in basement membranes. J Cell Biol 117: 1119-1133.

Yurchenco PD, Cheng YS, Schittny JC. 1990. Heparin modulation of laminin polymerization. J Biol Chem 265: 3981-3991.

Yurchenco PD, Tsilibary EC, Charonis AS, Furthmayr H. 1985. Laminin polymerization in vitro. Evidence for a two-step assembly with domain specificity. J Biol Chem 260: 7636-7644.

Zenker M, Aigner T, Wendler O, Tralau T, Muntefering H, Fenski R, Pitz S, Schumacher V, Royer-Pokora B, Wuhl E, et al. 2004. Human laminin $\beta 2$ deficiency causes congenital nephrosis with mesangial sclerosis and distinct eye abnormalities. Hum Mol Genet 13: 26252632.

Zhang RZ, Sabatelli P, Pan TC, Squarzoni S, Mattioli E, Bertini E, Pepe G, Chu ML. 2002. Effects on collagen VI mRNA stability and microfibrillar assembly of three COL6A2 mutations in two families with Ullrich congenital muscular dystrophy. J Biol Chem 277: 4355743564.

Zhou Y, Jiang D, Thomason DB, Jarrett HW. 2007. Laminininduced activation of Racl and JNKp46 is initiated by Src family kinases and mimics the effects of skeletal muscle contraction. Biochemistry 46: 14907-14916.

Zhou YW, Oak SA, Senogles SE, Jarrett HW. 2005. Laminin- $\{\alpha\} 1$ globular domains three and four induce heterotrimeric G-protein binding to $\{\alpha\}$-syntrophin's PDZ domain and alter intracellular $\mathrm{Ca}^{2+}$ in muscle. Am J Physiol Cell Physiol 288: C377-C388.

Zhou YW, Thomason DB, Gullberg D, Jarrett HW 2006. Binding of laminin $\alpha 1$-chain LG 4-5 domain to $\alpha$-dystroglycan causes tyrosine phosphorylation of syntrophin to initiate Racl signaling. Biochemistry 45: 2042-2052. 


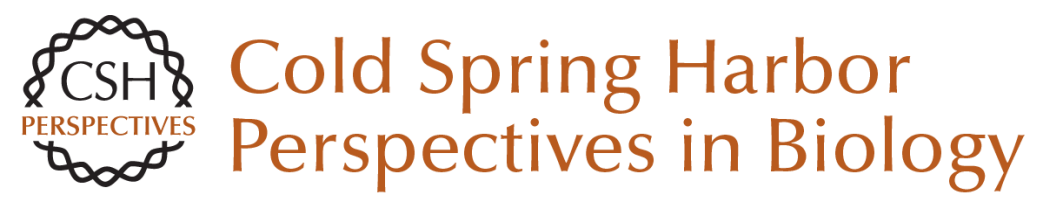

\title{
Basement Membranes: Cell Scaffoldings and Signaling Platforms
}

\author{
Peter D. Yurchenco
}

Cold Spring Harb Perspect Biol 2011; doi: 10.1101/cshperspect.a004911 originally published online December 8, 2010

\section{Subject Collection Extracellular Matrix Biology}

Extracellular Matrix in Development: Insights from Mechanisms Conserved between Invertebrates and Vertebrates Nicholas H. Brown

Extracellular Matrix Proteins in Hemostasis and Thrombosis Wolfgang Bergmeier and Richard O. Hynes

The Thrombospondins Josephine C. Adams and Jack Lawler

Cross Talk among TGF- $\beta$ Signaling Pathways, Integrins, and the Extracellular Matrix John S. Munger and Dean Sheppard

Heparan Sulfate Proteoglycans Stephane Sarrazin, William C. Lamanna and Jeffrey D. Esko

The Collagen Family Sylvie Ricard-Blum

Tenascins and the Importance of Adhesion Modulation

Ruth Chiquet-Ehrismann and Richard P. Tucker Integrin Structure, Activation, and Interactions lain D. Campbell and Martin J. Humphries
Extracellular Matrix Degradation and Remodeling in Development and Disease

Pengfei Lu, Ken Takai, Valerie M. Weaver, et al.

Overview of the Matrisome--An Inventory of Extracellular Matrix Constituents and Functions Richard O. Hynes and Alexandra Naba

Integrins in Cell Migration Anna Huttenlocher and Alan Rick Horwitz

Fibronectins, Their Fibrillogenesis, and In Vivo Functions Jean E. Schwarzbauer and Douglas W. DeSimone

Extracellular Matrix: Functions in the Nervous System

Claudia S. Barros, Santos J. Franco and Ulrich Müller

Molecular Architecture and Function of Matrix Adhesions

Benjamin Geiger and Kenneth M. Yamada

Cell-Extracellular Matrix Interactions in Normal and Diseased Skin

Fiona M. Watt and Hironobu Fujiwara

Genetic Analyses of Integrin Signaling

Sara A. Wickström, Korana Radovanac and Reinhard Fässler

For additional articles in this collection, see http://cshperspectives.cshlp.org/cgi/collection/

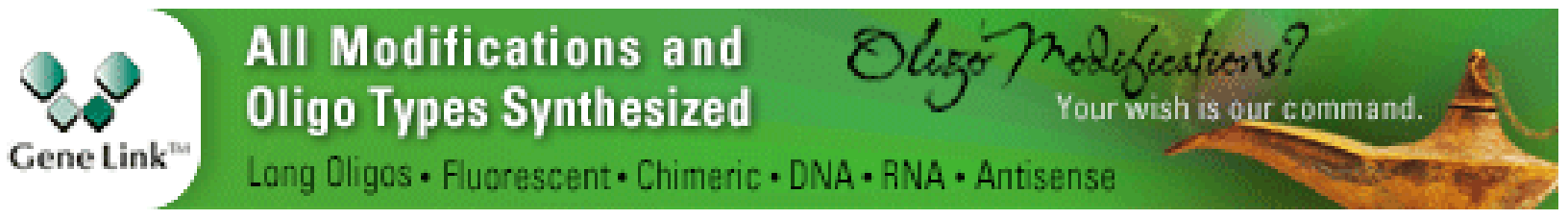

